\title{
Numerical Simulation of the Direct Radiative Effects of Dust Aerosol on the East Asian Winter Monsoon
}

\author{
Hui Sun ${ }^{1}$ and Xiaodong Liu ${ }^{1,2}$ \\ ${ }^{1}$ SKLLQG, Institute of Earth Environment, Chinese Academy of Sciences, Xian 710061, China \\ ${ }^{2}$ CAS Center for Excellence in Tibetan Plateau Earth Sciences, Beijing 100101, China
}

Correspondence should be addressed to Hui Sun; sunhui@ieecas.cn

Received 31 March 2015; Accepted 17 May 2015

Academic Editor: Hann-Ming H. Juang

Copyright (C) 2015 H. Sun and X. Liu. This is an open access article distributed under the Creative Commons Attribution License, which permits unrestricted use, distribution, and reproduction in any medium, provided the original work is properly cited.

Variations of the East Asian winter monsoon (EAWM) induced by dust aerosol are studied by using a regional climate model (RegCM4/Dust). Dust coupled and uncoupled experiments are carried out for the past decade (2000-2009). The coupled RegCM4 captures three centers of dust mixing ratio (DMR) located in the Taklamakan Desert, western Inner Mongolia, and northern Xinjiang, respectively, with maximum values greater than $500 \mu \mathrm{g} \mathrm{kg}^{-1}$ in winter. The surface total radiation change induced by dust is negative, and its central value of $-8 \mathrm{~W} \mathrm{~m}^{-2}$ results in surface temperature cooling by $1.5^{\circ} \mathrm{C}$ in winter. Dust induced radiation change at the top of the atmosphere (TOA) is also negative in Northern China, except over the Tibetan Plateau (TP), and up to $-5 \mathrm{~W} \mathrm{~m}^{-2}$ in Central China. Dust cooling effects increase the sea level pressure (SLP) gradient between land and ocean, the cold surge frequency, and the East Asian jet stream (EAJ) intensity and then enhance the EAWM. The dry and cold wind pervade most areas of East Asia, suppressing large-scale precipitation and eventually leading to a rainfall decrease of about 10-30\% in Northern China and the middle Yangtze River Valley.

\section{Introduction}

Aerosols are important atmospheric pollutants [1] and include particles of sulfate, black carbon, organic carbon, nitrate from human activities and dust, sea salt, and volcanic ash [2]. Over the past few decades, anthropogenic aerosols in East Asia have increased in line with enhancement of human activities [3]. Anthropogenic aerosols impact global climate through both direct and indirect effects $[4,5]$. With developing desertification in East Asia [6], the cycles and climatic effects of atmospheric dust, as a natural aerosol, have received widespread attention.

Dust aerosol is mainly produced from arid and semiarid deserts during strong dust storms. East Asia is a major dust source region with the Taklamakan and Gobi Deserts [7]. The occurrence of dust storms in East Asia is closely related to the development of Mongolian cyclone and cold fronts and frequently happens in spring [8]. In recent years, many general field campaigns have studied these processes, including the East Asian Study of Tropospheric Aerosol and Impact on Regional Climate (EAST-AIRC) [9], the Atmospheric
Radiation Measurement Mobile Facility mission in China (AMF-China), and the East Asian Study of Tropospheric Aerosols: International Regional Experiment (EAST-AIRE) [10]. These observations provide a basis for understanding dust aerosol particle properties, transport, and their climatic effects [9-11]. In addition, remote measurement platforms like the Cloud-Aerosol Lidar and Infrared Pathfinder Satellite Observation (CALIPSO) have provided three-dimensional dust distributions [12]. However, the above research methods cannot fully meet the demand for understanding the climatic effects of dust, as it is difficult to fully resolve dust aerosol effects from other factors in the real atmosphere. Therefore, many scholars have begun to use models to investigate dust aerosol climatic effects [13-15].

Many previous studies have simulated dust storm initiation processes [16-18], the direct radiative effects of dust on solar radiation $[19,20]$, and the particles' indirect effect on hydrology through acting as cloud condensation nuclei (CCN), thus modifying structure and properties of cloud [21, 22 . With respect to the climatic effects of dust, most previous simulations have mainly focused on the impact on the East 
Asian summer monsoon (EASM), using coarse resolution global climate models (GCMs) $[23,24]$, and their effects are still uncertain on regional scales since dust concentrations over East Asia tend to be systematically underestimated by GCMs $[25,26]$. This situation has been improved in recent years by the development of regional climate models (RCMs). For example, Zhang et al. [27] used the RegCM3/Dust model to simulate the dust aerosol effect on the East Asian climate; their results showed that the regional dust induced radiation change in the East Asian dust source region reached $-25 \mathrm{~W} \mathrm{~m}^{-2}$ in spring and induced surface cooling by $1^{\circ} \mathrm{C}$. The simulations of Sun et al. [28] showed that dust weakened the EASM, causing a rainfall decrease in Eastern and Southern China.

The EAWM is one of the most important circulation systems during winter in the Northern Hemisphere [29]. Its anomalies can impact the Mongolia High and Aleutian Low [30] but extend their influence by altering the position and strength of a Hadley cell such that the Australian summer monsoon is affected [31] and also causing abnormal weather in North America through changing EAJ [32]. Meanwhile, some loess [33, 34] and marine coral sediments [35] show that the dust cycle of East Asia has always had an important relationship with EAWM evolution and variability far back in the ancient geological record. Most studies to date have used meteorological station observations to determine dust storm frequency or reanalysis data $[36,37]$ to investigate the relationship between East Asian dust aerosol and EAWM variation. Conventional observation techniques cannot be used to study the effects of dust aerosols on the EAWM, winter rainfall, and temperature. Simulation work has mainly focused on the EASM, and simulation work concerning the EAWM is rare in addition to a number of observational studies [36, 38]. Coarse resolution GCM diagnosed dust aerosol radiative effects in winter were performed by Miller and Tegen [39], though their work did not investigate the dust impact on the EAWM and winter precipitation. In this paper we will use RegCM4/Dust to carry out simulations with long integration periods in East Asia to study the dust aerosol effects on EAWM and winter precipitation. First, we use observations to validate the simulated East Asian winter climatology, and then we analyze the dust aerosol distributions in winter in East Asia. Finally, we study dust aerosol effects on the EAWM to fill the gaps in this field.

\section{Numerical Model and Experiment Design}

2.1. Numerical Model. The selected model is the RegCM4 developed by ICTP. Due to its maturity, it is stable and simple to operate and has been widely applied to study regional climate and environmental change, particularly the simulation of Asian aerosol climatic effects [27, 40, 41]. RegCM4 is a hydrostatic model with a sigma coordinate system [28]. While retaining the basic core of RegCM3, new modules were added in RegCM4, including a new surface land module, the Community Land Surface Model V3.5 (CLM3.5), and successfully coupling ocean module [42]. The coupled dust module in RegCM4 is based on the dust producing model (DPM) of Marticorena and Bergametti [43] and Alfaro and
TABLE 1: Four dust bins and their optical properties in visible band.

\begin{tabular}{lccc}
\hline Dust bins size diameter $(\mu \mathrm{m})$ & $K_{\text {ext }}\left(\mathrm{m}^{2} \mathrm{~g}^{-1}\right)$ & $g$ & SSA \\
\hline $0.01-1$ & 2.45 & 0.71 & 0.95 \\
$1-2.5$ & 0.85 & 0.76 & 0.89 \\
$2.5-5$ & 0.38 & 0.81 & 0.80 \\
$5-20$ & 0.17 & 0.87 & 0.70 \\
\hline
\end{tabular}

Gomes [44] and includes dust emission, transport, dry and wet deposition, and optical and radiation properties [27, 45].

The dust size spectrum in the dust module ranges from 0.01 to $20.0 \mu \mathrm{m}$ including four transportable bins (or modes): the fine $(0.01-1.0 \mu \mathrm{m})$, accumulation $(1.0-2.5 \mu \mathrm{m})$, coarse $(2.5-5.0 \mu \mathrm{m})$, and giant $(5.0-20.0 \mu \mathrm{m})$ modes [45]. The RegCM4 employs the $\delta$-Eddington approximate for radiative flux calculations, and the optical spectrum ranges from 0.2 to $4.5 \mu \mathrm{m}$ including 18 wavelength bands [27]. One is in the visible band between 0.35 and $0.64 \mu \mathrm{m}$, seven bands are in the ultraviolet band between 0.2 and $0.35 \mu \mathrm{m}$, and the rest are in the infrared band. The effect of dust SW radiation is calculated using an asymmetry factor $(g)$, single scattering albedo (SSA), and mass extinction coefficient $\left(K_{\text {ext }}\right)$ based on Mie theory [27]. Refractive index of dust for the SW window is obtained from the Optical Properties of Aerosols and Clouds (OPAC) database [46], and Table 1 presents the dust optical properties in visible band $(0.35-0.64 \mu \mathrm{m})$.

In the LW domain, dust effects are accounted for introducing the dust emissivity (and hence absorptivity) following the parameterization of Kiehl et al. [47]. The dust LW emissivity is calculated according to

$$
\varepsilon_{\mathrm{LW}}(z)=1-\ell^{-D \cdot k_{\mathrm{lwabs}} \cdot b(z)},
$$

where $D=1.66$ is a diffusivity factor, $b(z)$ is the dust burden $\left(\mathrm{g} \mathrm{m}^{-2}\right)$ of a given layer, and $k_{\text {lwabs }}\left(\mathrm{m}^{2} \mathrm{~g}^{-1}\right)$ is the mass absorption coefficient calculated based on the Mie theory for each size bin of the relevant LW spectral window and the LW refractive indices are consistent with Wang et al. [48].

2.2. Experiment Design and Observational Data. We carried out two experiments in this paper. In the control experiment, the dust module was turned off (label: Nodust). The other experiment involved RegCM4 coupled with the dust module. Both were integrated from December 1, 1999, to December 31, 2009. The first month was the model spin-up, so data were analyzed from January 1, 2000, to December 31, 2009. This follows the experimental protocol of Sun et al. [28], though they only investigated dust effects on the EASM, while in this paper we focus on EAWM by using the same outputs. The above two experiments used prescribed SST from the National Oceanic and Atmospheric Administration (NOAA) [49] without coupled ROMS module.

The model horizontal resolution was $50 \mathrm{~km}$. The domain center was $\left(35.0^{\circ} \mathrm{N}, 105.0^{\circ} \mathrm{E}\right)$ with 160 grid cells in the $\mathrm{W}-\mathrm{E}$ direction and 95 in the $\mathrm{N}-\mathrm{S}$ direction. The model domain covered East Asia, South Asia, and the West Pacific Ocean (Figure 1(a)). Dust sources in our model included the Taklamakan Desert, western Inner Mongolia, and northern 


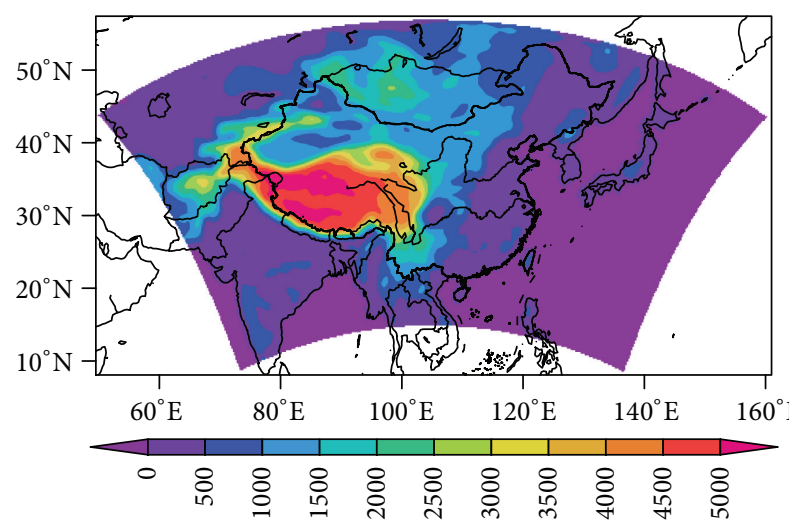

(m)

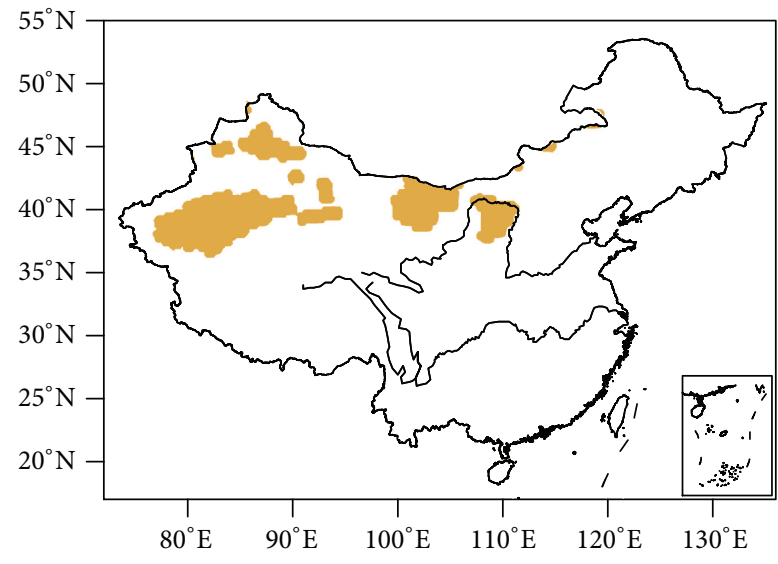

(b)

Figure 1: (a) The model domain (blue areas) and terrain height in meters and (b) the dust source distribution (yellow areas) in this study.

Xinjiang [50], displayed in Figure 1(b). The model was run with its standard configuration of 18 vertical $\sigma$-layers, with a maximum height of $10 \mathrm{hPa}$. The model initial and lateral boundary conditions were obtained from the National Centre for Environmental Prediction and Department of Energy (NCEP-DOE) Atmospheric Model Intercomparison Project (AMIP-II) reanalysis (R-2) [51]. The default land use types were from the Global Land Cover Characterization (GLCC) data [52].

A few observational data sets are used in this study for comparison with the simulated results. Monthly mean surface air temperature and precipitation data [53] with a high resolution $\left(0.5^{\circ} \times 0.5^{\circ}\right)$ are provided by the Climate Research Unit (CRU), the University of East Anglia. The NCEP-DOE reanalyses $\left(2.5^{\circ} \times 2.5^{\circ}\right)$ are used to validate SLP, wind fields at $850 \mathrm{hPa}$ and $200 \mathrm{hPa}$ simulated with RegCM4. Multi-angle Imaging SpectroRadiometer (MISR) aboard the NASA Earth Observation System's Terra satellite Level 3 monthly mean aerosol optical depth (AOD) from 2000 to 2009 is used to validate RegCM4/Dust simulated dust AOD distribution. Besides, the in situ observed monthly mean AOD from Aerosol Robotic Network (AERONET) is used to evaluate the model simulated seasonal and interannual variations of dust AOD.

\section{Results of Simulations}

\subsection{Validation}

3.1.1. Basic Model Climatology. The SLP, surface wind, $850 \mathrm{hPa}$ atmospheric circulation, and EAJ represent the main characteristics of the EAWM [54], and we first validated the above variables by using the NCEP-DOE reanalysis (Figure 2). The center position of the Siberian High was well simulated by RegCM4 with a weak bias of 1-2 Pa compared with the NCEP-DOE reanalysis. The prominent surface features of the EAWM were well captured by RegCM4, that is, the strong northwesterly wind along the East Asian coast [55] (Figures 2(a) and 2(b)). In winter, the most dominant features of the EAWM are the northwesterly wind or northerlies in the lower troposphere [56]. These were well captured by RegCM4 (Figures 2(c) and 2(d)), except for the strong northwesterly wind in central South China. On the other hand, the simulated intensity and location of the EAJ agreed with the NCEP-DOE reanalysis; that is, the intensity of the EAJ reached up to $65 \mathrm{~m} \mathrm{~s}^{-1}$ (U component of wind) and its axis was located at $30^{\circ} \mathrm{N}$ (Figures $2(\mathrm{e})$ and $2(\mathrm{f})$ ). The above validations indicate that the model simulated reasonable East Asian winter climatology.

3.1.2. Comparison between Simulated Dust AOD and the MISR Observed $A O D$. The seasonal mean climatological distributions of MISR observed aerosol AOD and RegCM4/Dust simulated dust AOD during 2000-2009 are shown in Figure 3. Both model simulation and satellite observation capture the seasonal evolution of dust AOD, increasing in spring and summer and decreasing in autumn and winter over West China. The model captures the areas of maximum dust AOD in the Taklamakan Desert, Gobi Desert, and northern Xinjiang. It should be mentioned that MISR retrieval includes all types of aerosols, while the model only describes dust aerosol. Therefore, the above comparison may have some limitations. Actually, MISR-retrieved Angstrom exponent, which is inversely related to the average size of the particles in the aerosol, can be used to distinguish dust versus pollution aerosols and evaluates the model performance. The bigger the particles, the smaller the exponent. As shown in Figure 3, the exponent is smaller in Taklamakan and Gobi Desert in spring, autumn, and winter, which is consistent with that of higher dust AOD simulated by RegCM4/Dust in these seasons. The exponent in summer is higher than that in the remaining three seasons in the two deserts, so the model may overestimate the dust AOD in summer.

In addition, we carried out a comparison between in situ observed monthly mean AOD from AERONET and that simulated by the model at Dalanzadgad $\left(43.6^{\circ} \mathrm{N}, 104.4^{\circ} \mathrm{E}\right)$. It is the only AERONET site available in the domain of interest with continuous AOD values more than ten years. The comparison 


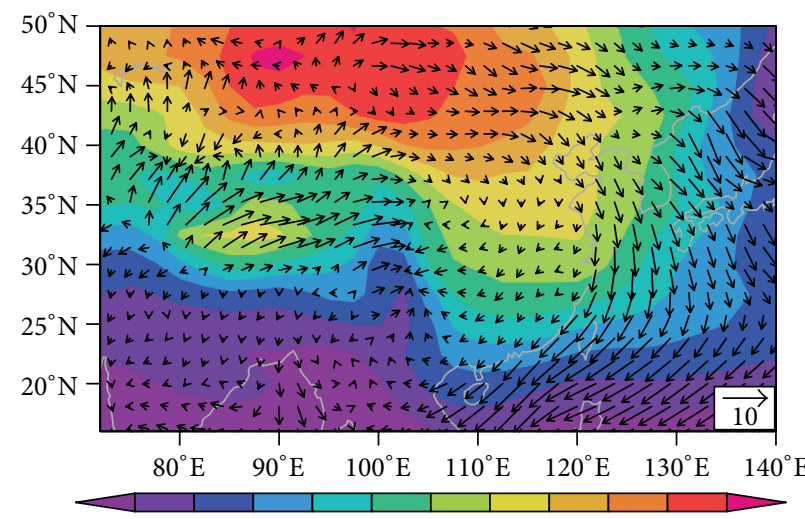

10141016101810201022102410261028103010321034 (hPa)

(a)

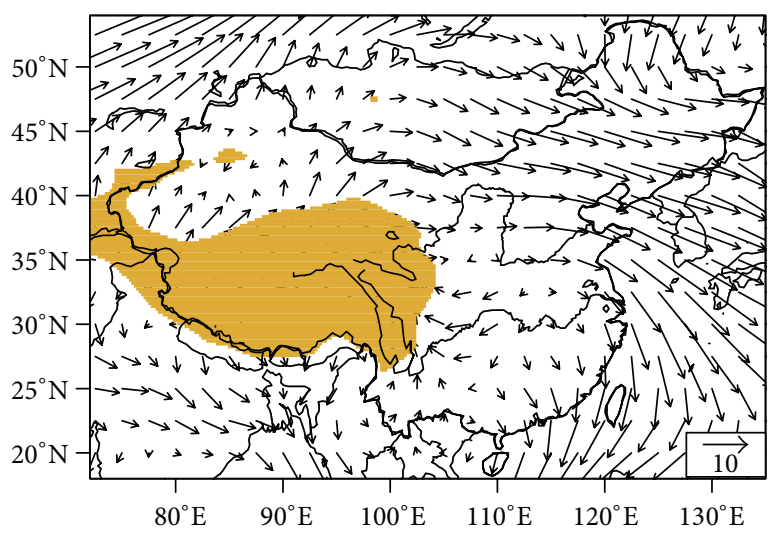

(c)

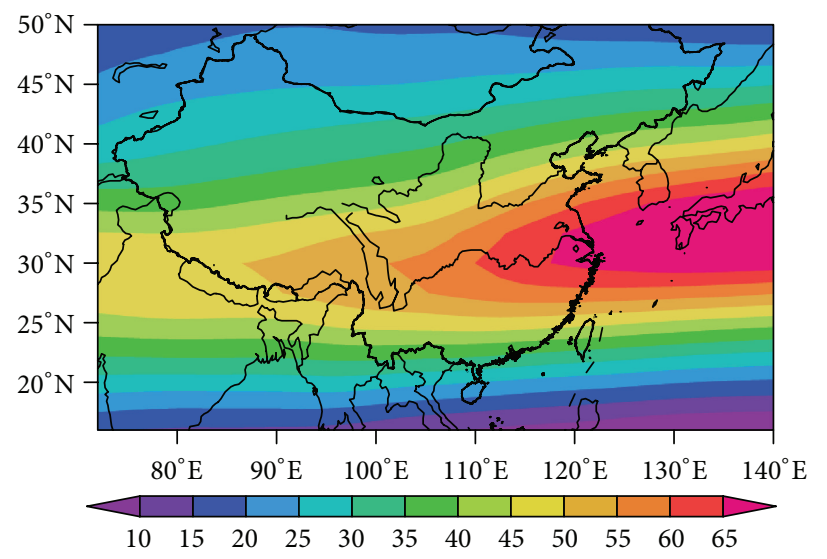

(e)

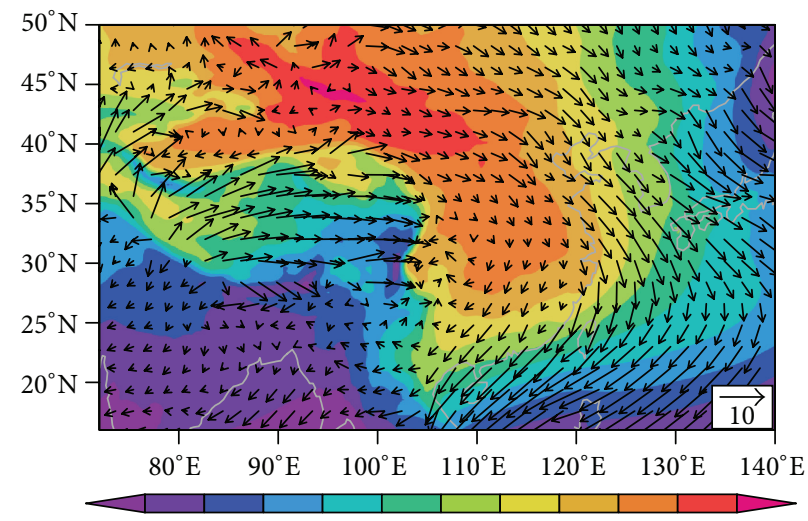

10141016101810201022102410261028103010321034 (hPa)

(b)

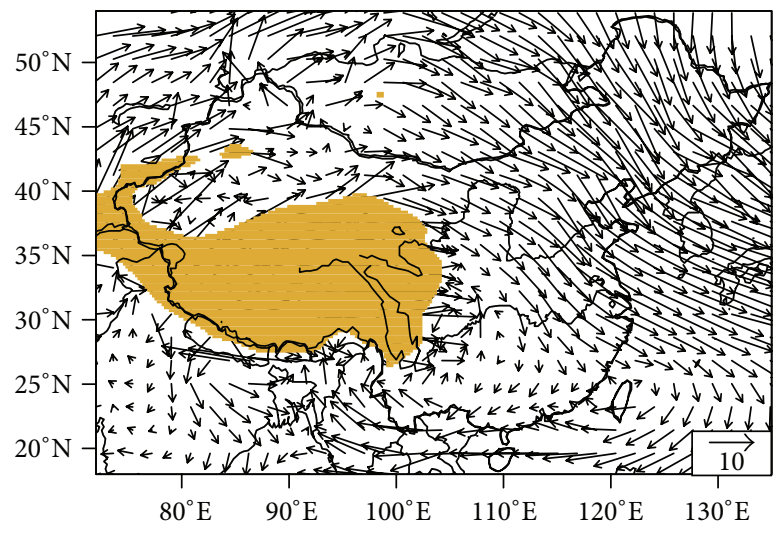

(d)

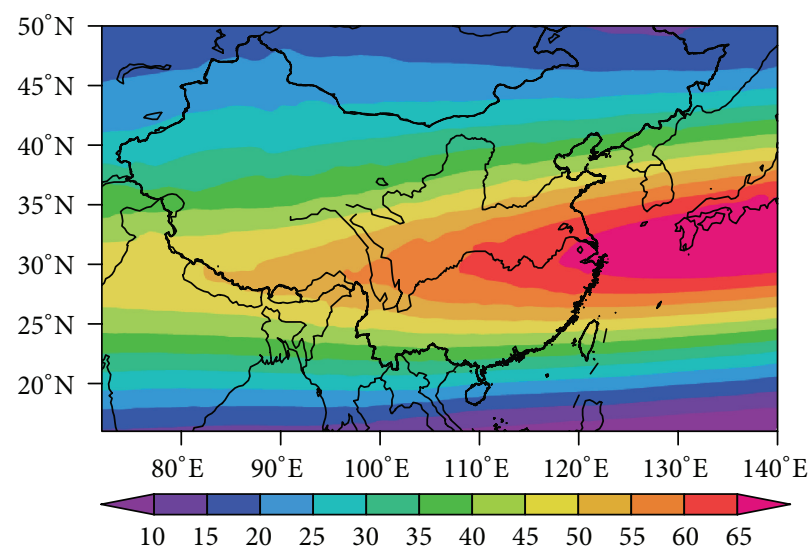

(f)

Figure 2: Comparison between the NCEP-DOE reanalysis ( $a, c, e)$ and Nodust experiment simulated (b, d, f), the SLP (hPa) superimposed on the surface wind $\left(\mathrm{m} \mathrm{s}^{-1}\right)(\mathrm{a}, \mathrm{b})$, the $850 \mathrm{hPa}$ wind $(\mathrm{c}, \mathrm{d})$, and the $200 \mathrm{hPa} \mathrm{U}$ component of wind (e, f), averaged in winter (DJF) during 2000-2009 period. The yellow area in (c, d) represents the topography below $850 \mathrm{hPa}$ altitude.

shows that the seasonal and interannual variations of AOD at this site are well captured by RegCM4/Dust (Figure 4).

3.2. Dust Mixing Ratio. The horizontal and vertical distributions of dust directly determine its climatic effects, so we discuss the simulated dust distribution before analyzing the climatic effects of dust. The coupled RegCM4 simulated three maximum centers of the DMR in Northern China (Figure 5(a)). They were in the Taklamakan Desert, northern Xinjiang, and western Inner Mongolia, where the DMRs were 


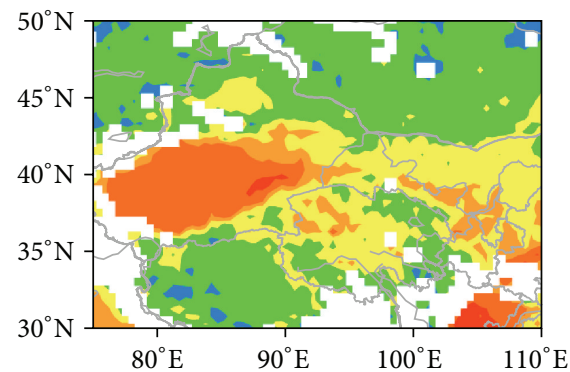

(a)

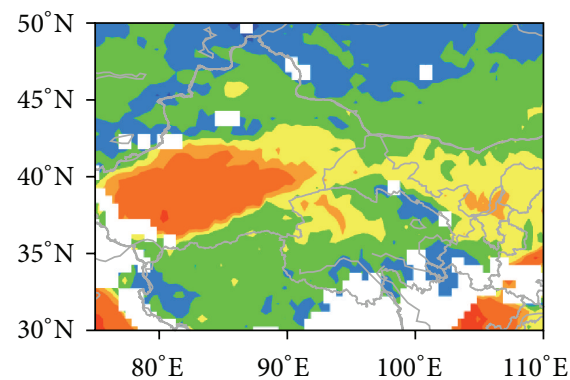

(b)

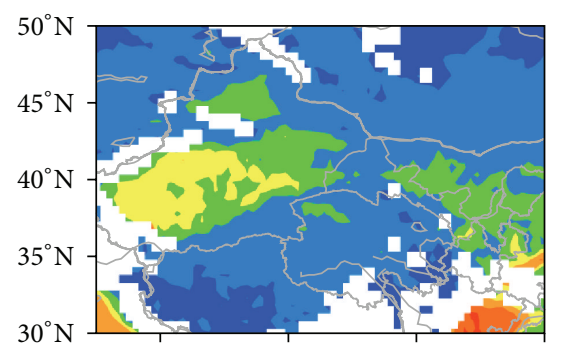

$80^{\circ} \mathrm{E} \quad 90^{\circ} \mathrm{E}$

(c)

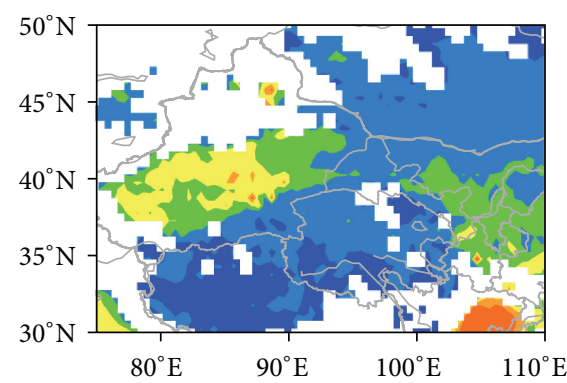

(d)

$\begin{array}{llllllll}0.1 & 0.2 & 0.3 & 0.4 & 0.5 & 0.7 & 0.9 & 1\end{array}$

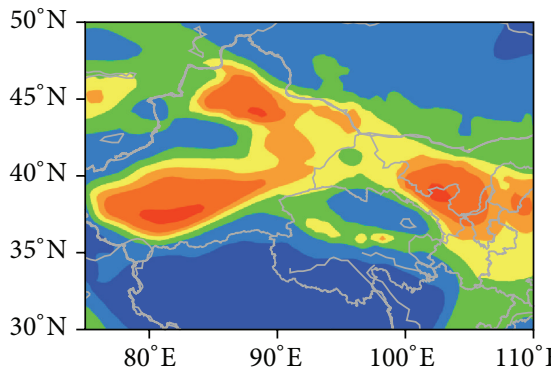

(e)

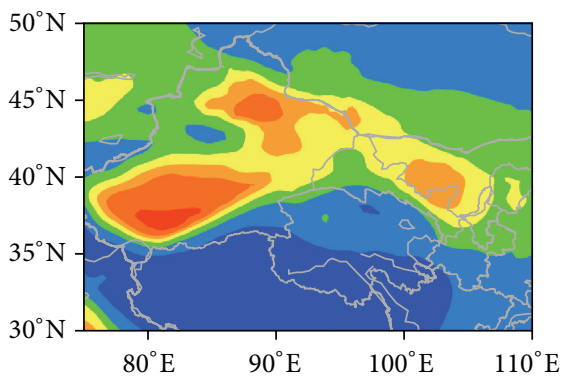

(f)

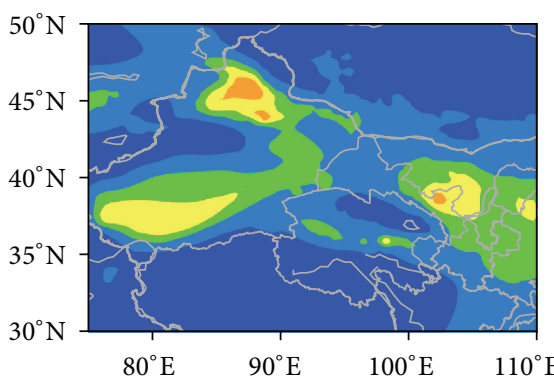

(g)

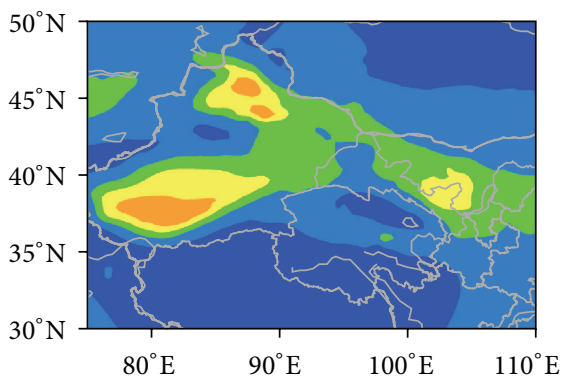

(h)

$\begin{array}{llllllll}0.1 & 0.2 & 0.3 & 0.4 & 0.5 & 0.7 & 0.9 & 1\end{array}$

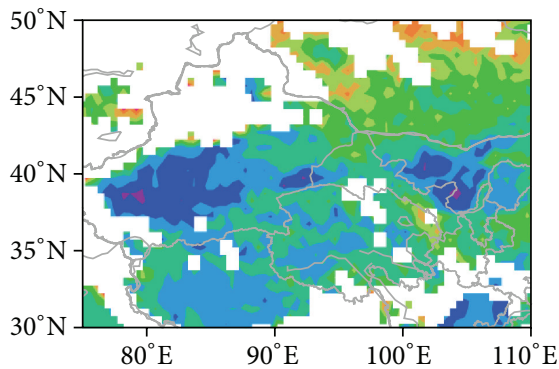

(i)

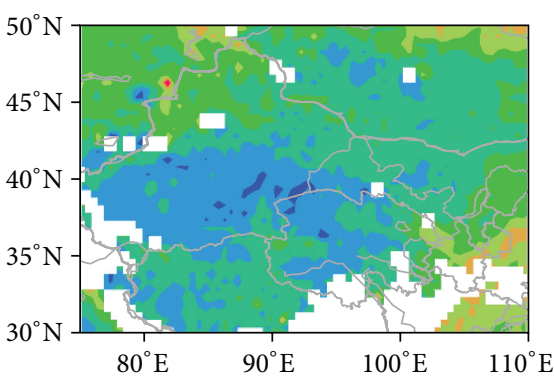

(j)

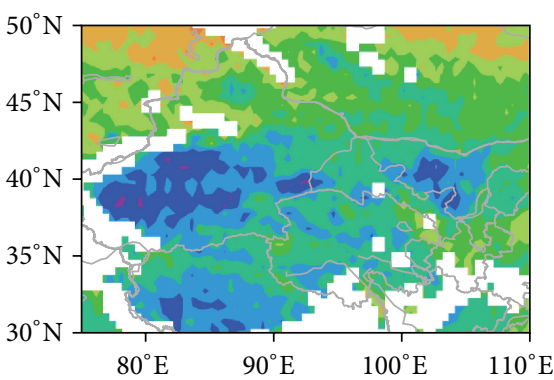

(k)

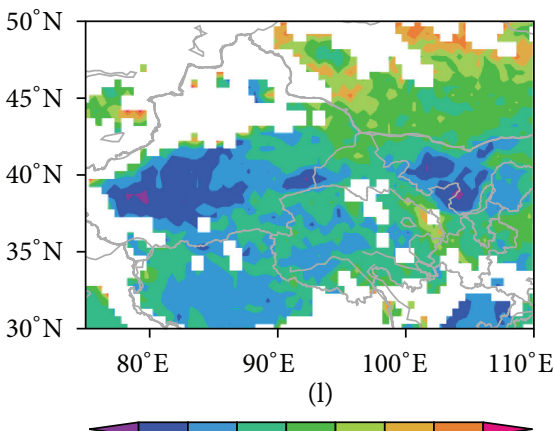

$\begin{array}{lllllllll}0.4 & 0.6 & 0.8 & 1 & 1.2 & 1.4 & 1.6 & 1.8\end{array}$

FiguRE 3: MISR-retrieved AOD (555 nm) (left-hand panels), the RegCM4 simulated dust AOD (550 nm) (middle panels), and MISR-retrieved Angstrom exponent (right-hand panels) averaged in (a, b) spring, (c, d) summer, (e, f) autumn, and (g, h) winter during 2000-2009 period.

all greater than $500 \mu \mathrm{g} \mathrm{kg}^{-1}$. Zakey et al. [45] simulated the DMR during a dust storm in the Sahara desert and found that it could reach $450 \mu \mathrm{g} \mathrm{kg}^{-1}$. Our simulated value was close to their simulation. The DMR was also higher in the CLP and the areas to the south of CLP, with the DMR greater than $300 \mu \mathrm{g} \mathrm{kg}^{-1}$, because these areas were influenced by strong northwesterly winds and high frequency cold surges in winter (Figures 2(d) and 9(a)).
The DMR vertical profiles (Figure 5(b)) show that dust was transported downstream by strong westerly and ascending motions, consistent with the simulations of Shi and Liu [57]. The upward motion was stronger in the Taklamakan Desert than in its downstream areas, and dust reached $300 \mathrm{hPa}$ where there were strong convective activities. In winter, dust storms frequently outbreak in western Inner Mongolia accompanied with the movement of Mongolia 


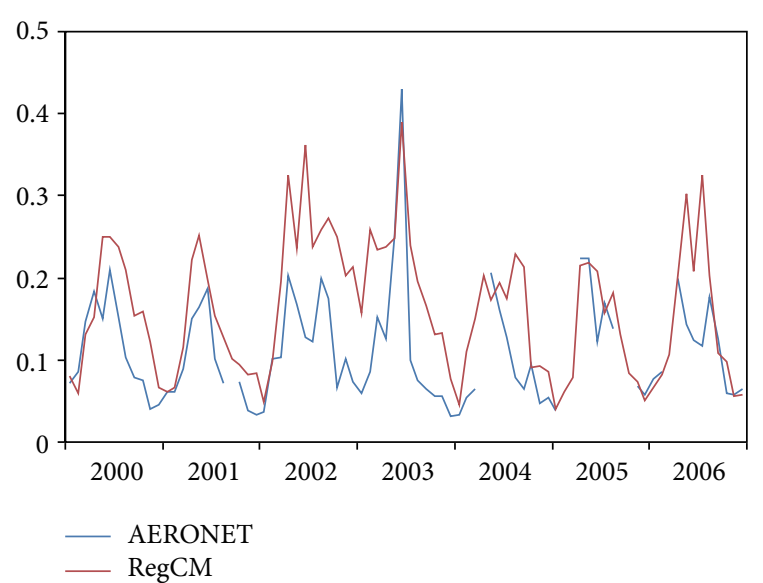

FIgURE 4: Variations of monthly mean AOD at Dalanzadgad from AERONET observations $(500 \mathrm{~nm})$ and that near the grid of Dalanzadgad simulated by the model.

cyclone. The diffusion conditions of this area are stronger than those over the Taklamakan Desert [58], and the DMR is also higher (Figure 5(c)).

\subsection{Effect of Dust on the East Asian Winter Climate}

3.3.1. Dust Direct Radiative Forcing. Figure 6 shows the radiation changes of the coupled RegCM4 simulation induced by dust averaged for ten years under clear sky conditions at the TOA (shortwave, SW, and longwave, LW) in winter. Simulated surface SW change in winter is the strongest in the three key desert regions. The SW change can reach $-25 \mathrm{~W} \mathrm{~m}^{-2}$ in the central Taklamakan Desert (Figure 6(a)). The LW radiation at surface showed large positive anomalies coinciding with the Taklamakan Desert and can reach $16 \mathrm{~W} \mathrm{~m}^{-2}$ (Figure 6(c)) resulting from the dust induced surface cooling (Figure 7(d)). The dust induced surface total radiation change (SW + LW) over East Asian was negative with a magnitude of $-8 \mathrm{Wm}^{-2}$ over the Taklamakan Desert, northern Xinjiang, western Inner Mongolia, the CLP, and the areas to the south of CLP (Figure 6(e)). The RCMs simulated total surface radiation change was stronger than the simulations of Miller and Tegen [39] who gave a range of -5 to $5 \mathrm{~W} \mathrm{~m}^{-2}$ total surface radiation change in winter by using a GCM.

Figure 6(b) shows that dust induced clear sky TOA SW radiation change in winter is also negative and its center located in the downstream area of North-Central China where surface dust concentration is the highest. The magnitude of LW change at TOA is smaller than that at surface (Figure 6(d)) because of the absorption of LW by the dust. Except over the TP, dust induced TOA total radiation changes were also negative. The regions in which change was significant were located in Central China and western Inner Mongolia, because of the high concentration of dust there (Figure 6(f)). The total radiation change was the highest there with a value greater than $-5 \mathrm{~W} \mathrm{~m}^{-2}$. Dust induced TOA total radiation change over the TP was positive and reached $5 \mathrm{~W} \mathrm{~m}^{-2}$, consistent with Miller and Tegen [39] who gave a TOA total radiation change in the range of $-2 \mathrm{~W} \mathrm{~m}^{-2}$ to $2 \mathrm{~W} \mathrm{~m}^{-2}$ in Central China.

3.3.2. Temperature. Figures $7(\mathrm{a})$ and $7(\mathrm{c})$ compare the Nodust simulations and CRU observations for averaged winter surface air temperature. Generally, RegCM4 captured the spatial distribution of the winter surface air temperature, including the decrease from the southeast to the northwest, but the model simulated a $2-4^{\circ} \mathrm{C}$ cold bias in Southern China. In the Dust experiment, the surface temperature in the Taklamakan Desert was lower than those of the Nodust simulations (Figure 7(b)). Dust cools the surface in winter, and there were two significant cooling regions in East Asia: the Taklamakan Desert, induced by high dust emission (Figure 5(a)), and the middle reaches of the Yangtze River, because of the high concentration of dust aerosol from the western Mongolia desert carried by strong northwesterly winds (Figures 5(b) and 5(c)). The cooling in the above two regions exceeded $1.5^{\circ} \mathrm{C}$ (Figure $7(\mathrm{~d})$ ). This cooling effect is stronger than the GCM simulation of Miller and Tegen [39].

3.3.3. Circulation. Figure 8 shows the SLP and the $850 \mathrm{hPa}$ atmospheric circulation anomaly induced by direct dust radiative effects. Dust cooling effects increased the SLP in Northern and Eastern China and deceased SLP over the West Pacific Ocean. Therefore, the land-ocean pressure gradient was enhanced (Figure 8(a)), leading to EAWM strengthening (Figure 8(b)). The westerly wind in Western China and the northerly wind in south of the CLP increased to $1.5 \mathrm{~m} \mathrm{~s}^{-1}$.

The East Asian winter cold surge frequency can represent the intensity of the winter monsoon. The definition of a cold surge is that the north wind has a speed greater than $5 \mathrm{~m} \mathrm{~s}^{-1}$, persistent for two days or more [59]. Compared to the Nodust experiment (Figure 9(a)), the Dust experiment had the frequency of cold surge significantly increased by 15\% (averaged in box area in Figure 9(c)) in Northern China. We further examined the EAJ change induced by dust. The position of the EAJ axis was $30^{\circ} \mathrm{N}$ in winter (Figure 2(e)), and the intensity of the jet was enhanced significantly in the area of $30-40^{\circ} \mathrm{N}$ (not shown).

3.3.4. Precipitation. Precipitation is an important variable affecting atmospheric dust transport and settlement. Figures 10(a) and 10(c) compare the Nodust simulations and CRU observations for averaged winter precipitation rate. The CRU observed winter precipitation showed precipitation over Northwest China was less than $1 \mathrm{~mm} \mathrm{day}^{-1}$ and the wettest area was located in Southeast China, where winter precipitation rate exceeded $3 \mathrm{~mm} \mathrm{day}^{-1}$ (Figure 10(c)). In the Nodust experiment (Figure 10(a)), RegCM4 captured the spatial pattern of the winter precipitation rate, including the reasonable southeast to northwest decreasing gradient, but underestimated the precipitation over Southeast China. Additionally, RegCM4 overestimated the precipitation over the northern TP and the Tian Shan, because in these areas rainfall was sensitive to the cumulus parameterization scheme [60]. In the Dust experiment, the precipitation decreased in comparison to the Nodust experiment 


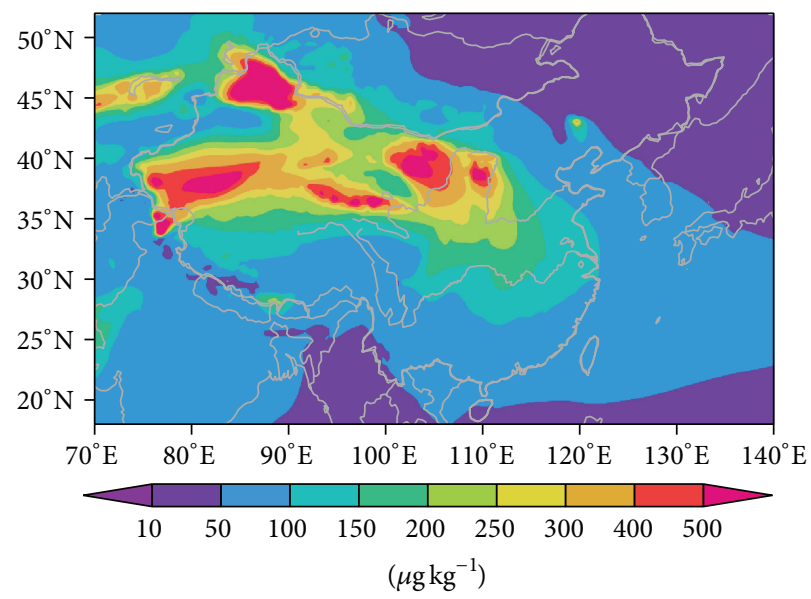

(a)

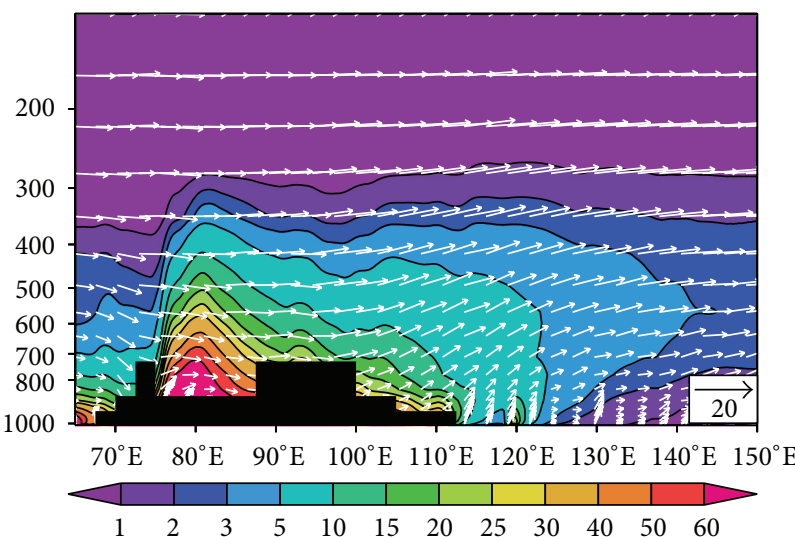

(b)

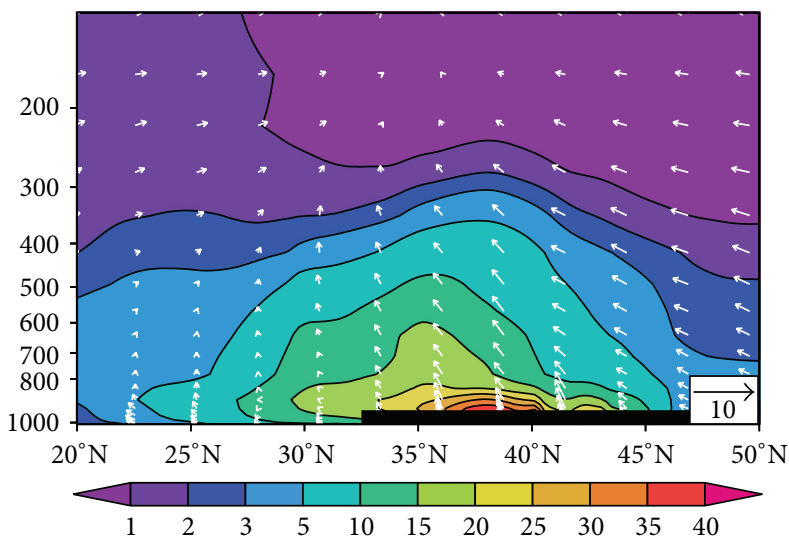

(c)

Figure 5: (a) The RegCM4 simulated dust mixing ratio horizontal distribution and (b) longitude-height cross section (averaged over 35$50^{\circ} \mathrm{N}$ ) and (c) latitude-height cross section (averaged over $105-120^{\circ} \mathrm{E}$ ) for vertical wind field $\left(\mathrm{Pa} \mathrm{s}{ }^{-1}\right.$, white vector) and the dust mixing ratio ( $\mu \mathrm{g} \mathrm{kg}^{-1}$, color shaded) in winter during 2000-2009 period.

(Figure 10(b)). Both Nodust and Dust experiments underestimated the precipitation over Southeast China, and the less-predicted rainfall could be related to the model physics when applying to the region; for example, the Grell mass flux scheme may be more suitable for midlatitudes rather than the tropical and subtropical areas of China [61]. As the EAWM strengthened (Figure 8(b)), enhanced dry and cold air spread throughout Northern China, and precipitation in the northeastern and middle Yangtze River valley decreased by about $10-30 \%$ (Figure 10(d)).

\subsection{Relationship between Asian Dust and the EAWM at the} Interannual Scale. Dust cycle and the EAWM can influence each other. Year-to-year variations of some winter (December-February) meteorological elements can further show the effect of dust. As shown in Figure 11, there is a clear interannual variation for winter dust AOD in the Taklamakan Desert as the largest dust source in Asia (Figure 11(a)). The dust induced change in winter surface temperature in Taklamakan Desert reduces with the dust AOD increasing (Figure 11(b)). It is more interesting to observe a positive relationship between year-to-year winter dust AOD and dust induced change of the EAWM index (Figure 11(c)), which was calculated to reflect the large-scale winter monsoon intensity according to the definition of Gong et al. [62]. Consistently, the winter precipitation in North China $\left(38^{\circ}-\right.$ $42^{\circ} \mathrm{N}, 110^{\circ}-120^{\circ} \mathrm{E}$ ) (Figure $11(\mathrm{~d})$ ) decreases (increases) with the strengthening (weakening) of winter monsoon in terms of year-to-year variations. The above comparisons indicate that dust can enhance the EAWM, and the effect is stronger in the years with more dust.

On the other hand, the EAWM change may module the surface meteorological parameters and dust cycle. Figure 12 shows year-to-year variations of the EAWM index and water vapor mix ratio at $2 \mathrm{~m}$ above surface over the Taklamakan Desert in the Nodust experiment in comparison with those in the Dust experiment. The surface wetness in Taklamakan Desert decreases in both the Nodust and Dust experiments in strong monsoon years (2006 and 2008), but the reduction in the Dust experiment is more than that in the Nodust experiment. However, the surface wetness increases in both the Nodust and Dust experiments in weak monsoon years (2001-2004), and the increase in the Nodust experiment is more than that in the Dust experiment. It implies 


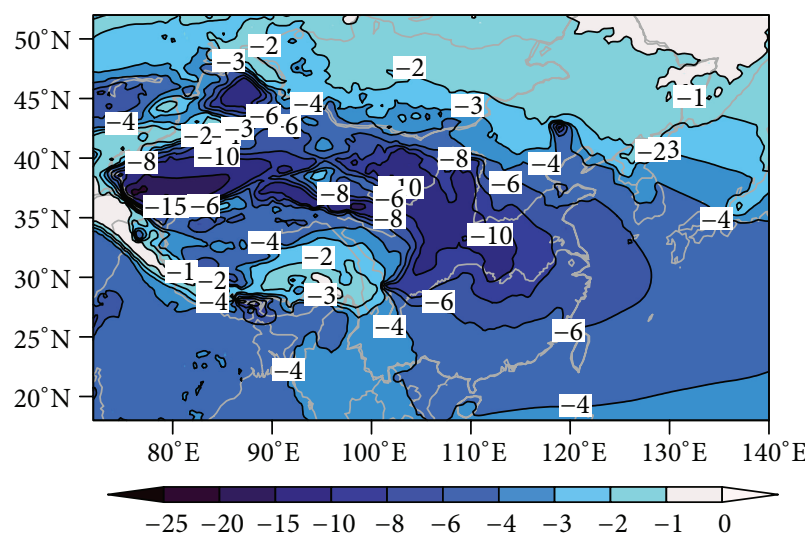

(a)

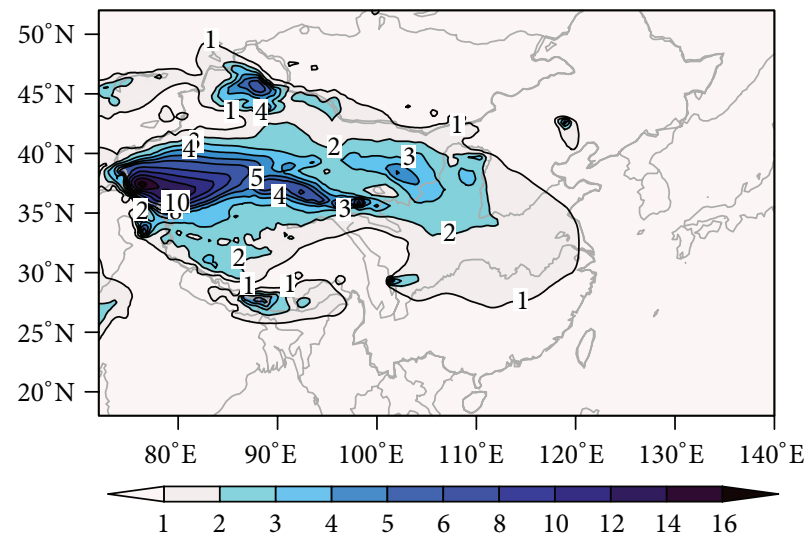

(c)

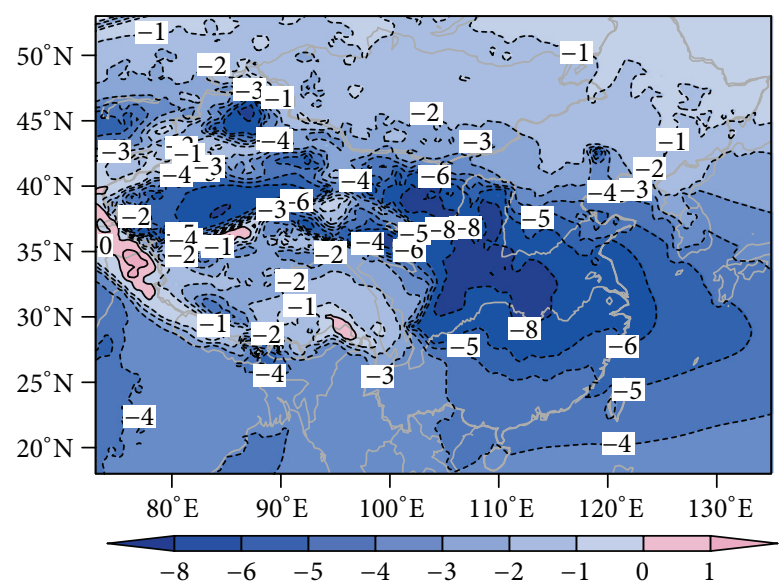

(e)

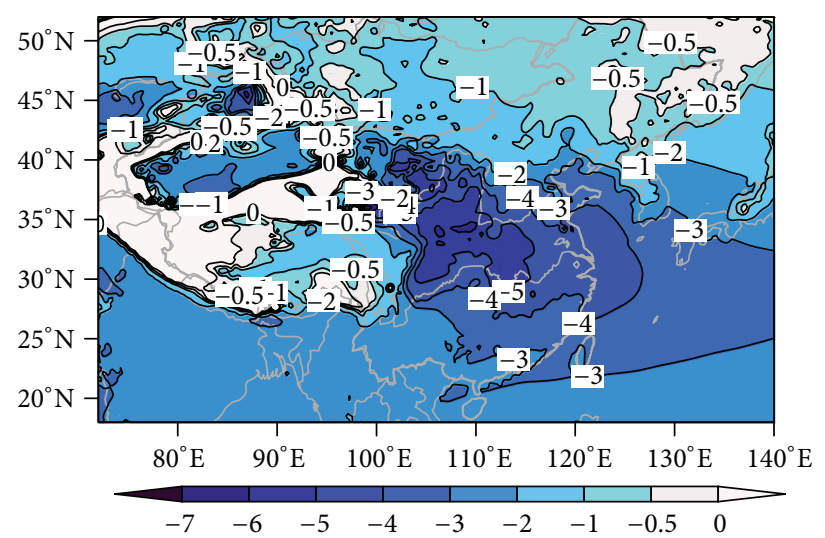

(b)

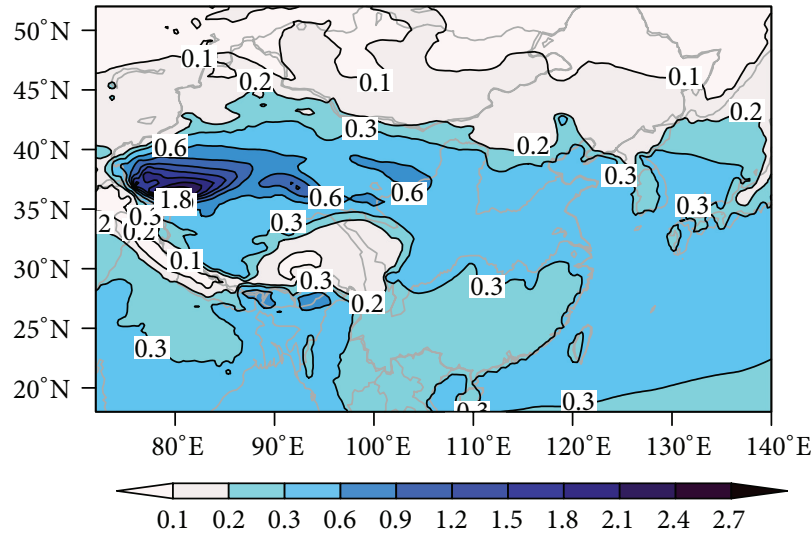

(d)

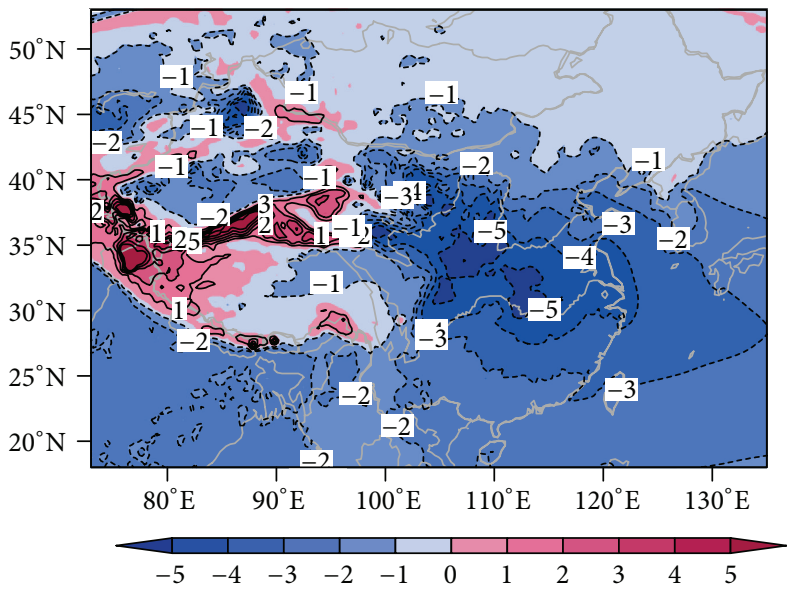

(f)

Figure 6: Simulated dust induced clear sky (a, b) SW, (c, d) LW, and (e, f) total radiation (SW plus LW, W $\mathrm{m}^{-2}$ ) changes at (a, c, e) the surface and $(b, d, f)$ the TOA, averaged in winter during 2000-2009 period.

the enhancement of the EAWM may cause the dust emission increasing.

\section{Conclusion and Discussions}

With the deterioration of the natural environment, atmospheric dust aerosol greatly affects global climate. The impact of dust on climate has been recognized only at the global scale in most previous research $[14,19,39]$ and the studies of dust aerosol on a regional scale have not elucidated its climatic effects, especially on the EAWM. This paper used the latest version of RegCM4/Dust, to carry out coupled and uncoupled Dust experiments with a resolution of $50 \mathrm{~km}$ over East Asia from 2000 to 2009. Using the simulation 


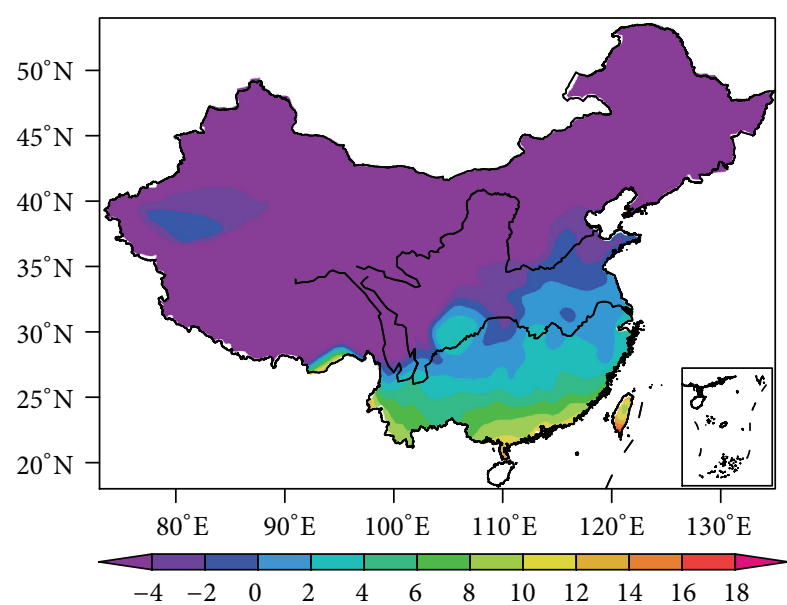

(a)

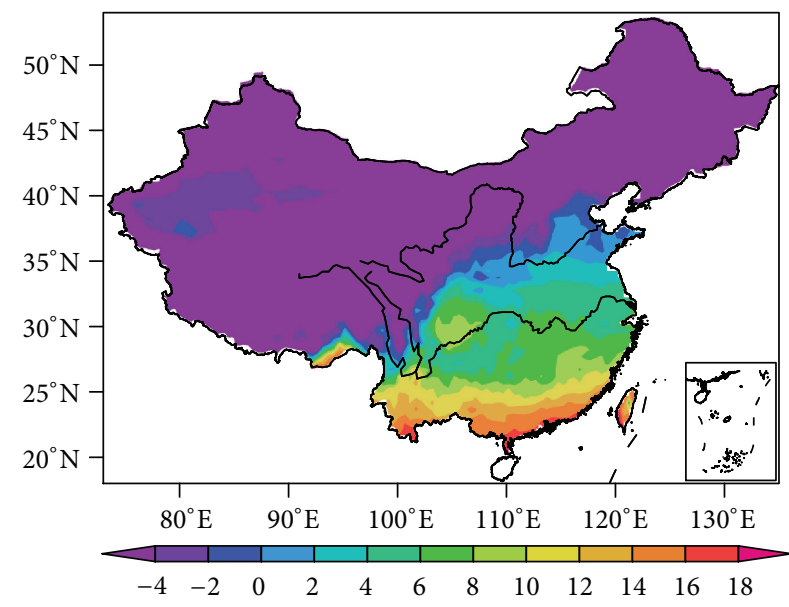

(c)

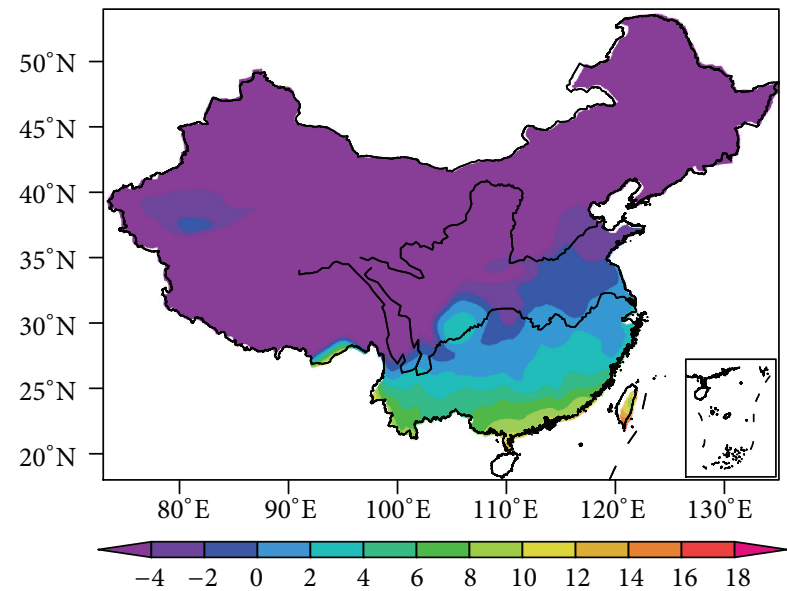

(b)

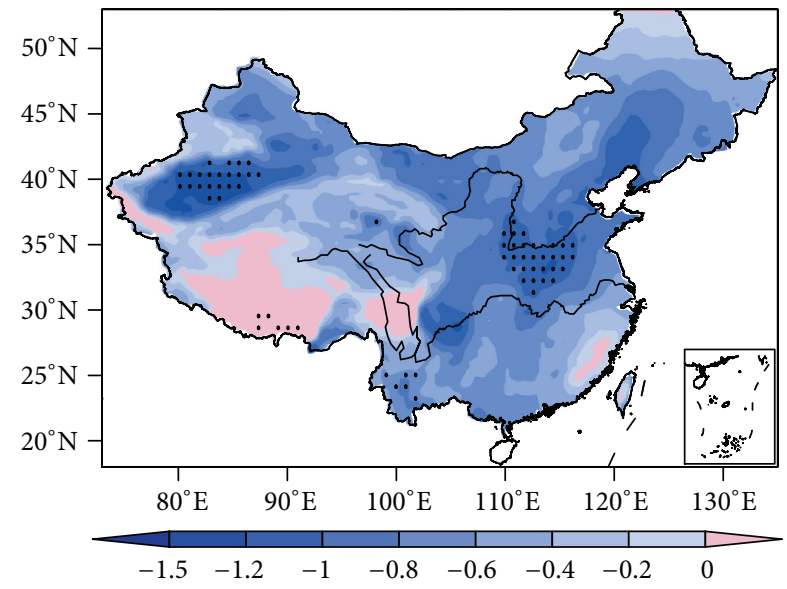

(d)

FIGURE 7: Surface air temperature at $2 \mathrm{~m}\left({ }^{\circ} \mathrm{C}\right)$ for (a) Nodust, (b) Dust, (c) CRU, and (d) difference between Dust and Nodust experiments averaged in winter during 2000-2009 period; the black dotted area in (d) indicates areas in which the difference is statistically significant at the $95 \%$ confidence level (Student's $t$-test).

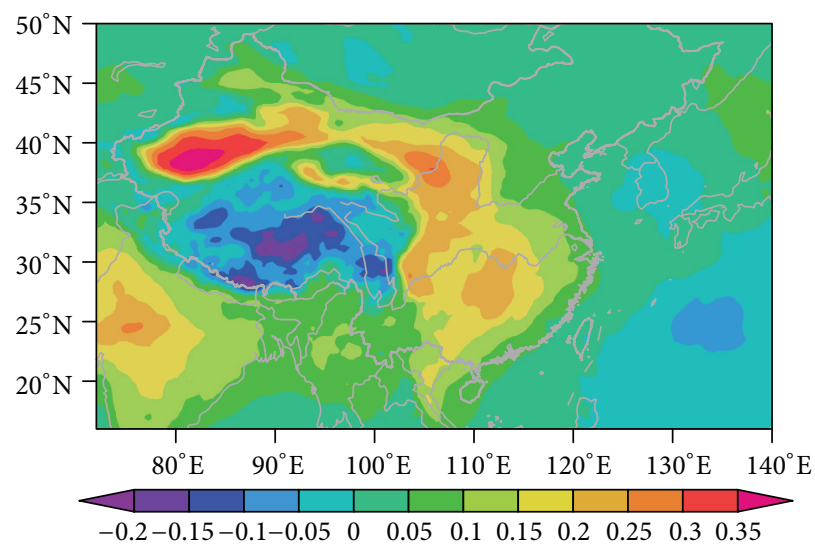

(a)

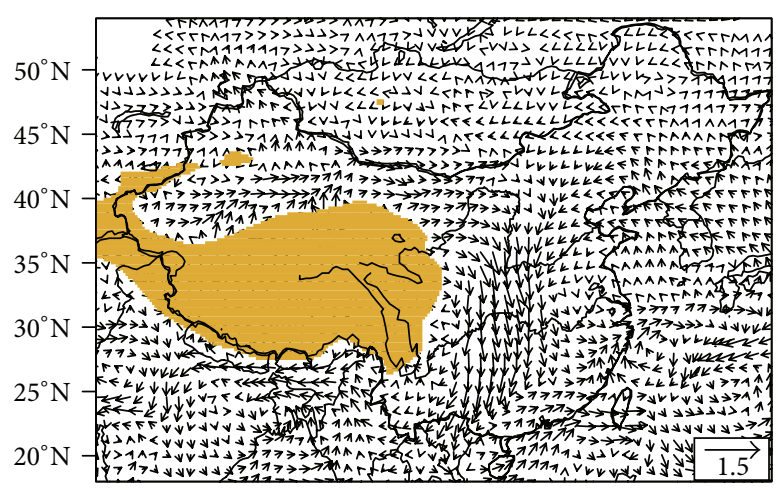

$(\mathrm{hPa})$

(b)

FIGURE 8: The simulated (a) SLP and (b) $850 \mathrm{hPa}$ wind differences in $\mathrm{m} \mathrm{s}^{-1}$ between Dust and Nodust experiments averaged in winter during 2000-2009 period. 


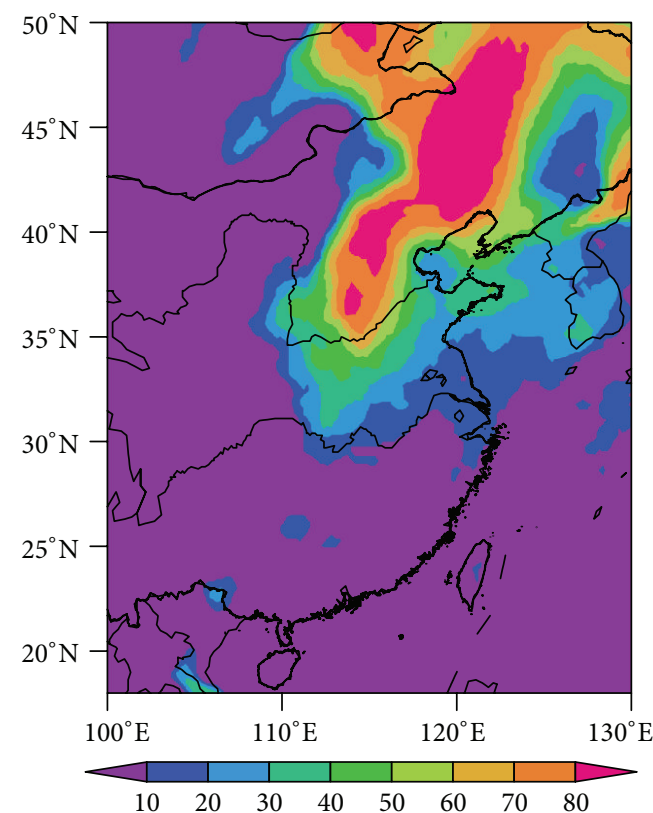

(a)

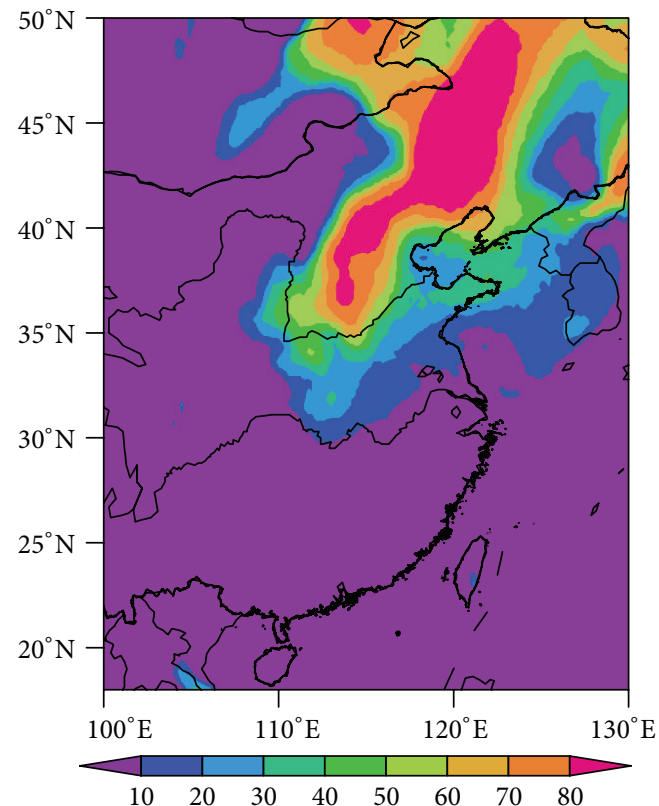

(b)

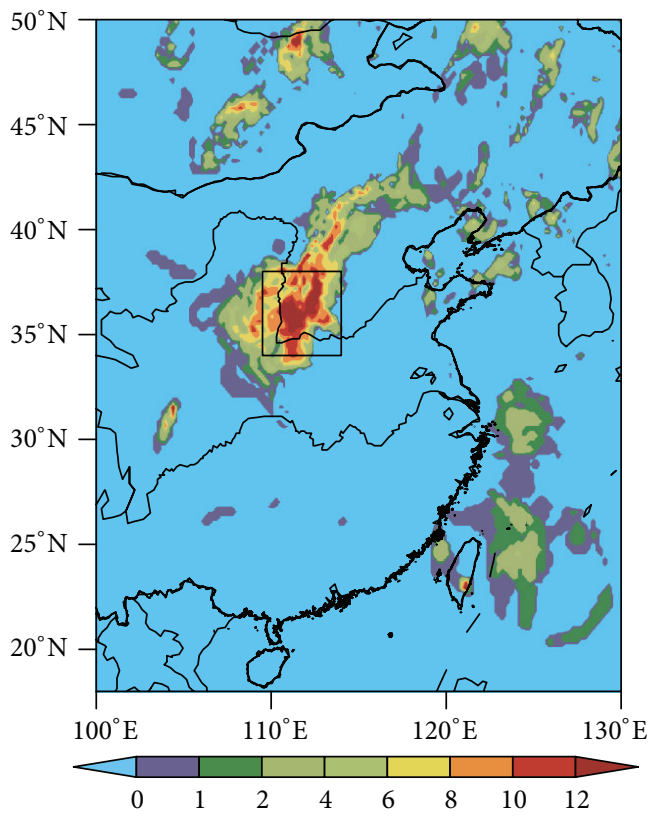

(c)

FIGURE 9: The simulated cold surge frequency in winter for the (a) Nodust and (b) Dust experiments and (c) the differences (Dust minus Nodust) averaged in winter during the 2000-2009 period. The box region will be used to compare the differences between Dust and Nodust experiments.

results, we investigated the climatic effects of dust in East Asia including its direct radiative effects and its effects on surface temperature, atmospheric circulation, and precipitation.

In winter, the DMR in the Taklamakan Desert, northern Xinjiang, and western Inner Mongolia was the highest, reaching $500 \mu \mathrm{g} \mathrm{kg}^{-1}$, while in CLP and the areas to the south of the CLP, due to the strong westerly and northerly winds, the DMR was high at $300 \mu \mathrm{g} \mathrm{kg}^{-1}$. Compared to previous work [27, 45, 57], our simulation was reasonable. Surface dust induced radiation change was negative in winter, and the centers located in the Taklamakan Desert, western Inner Mongolia, CLP, and the areas to the south of CLP. The surface radiation change in the dust source centers reached $-8 \mathrm{~W} \mathrm{~m}^{-2}$. Areas with a significant change in the TOA radiation were located in Taklamakan and Central China. The strong effect of dust radiation interaction caused the East 


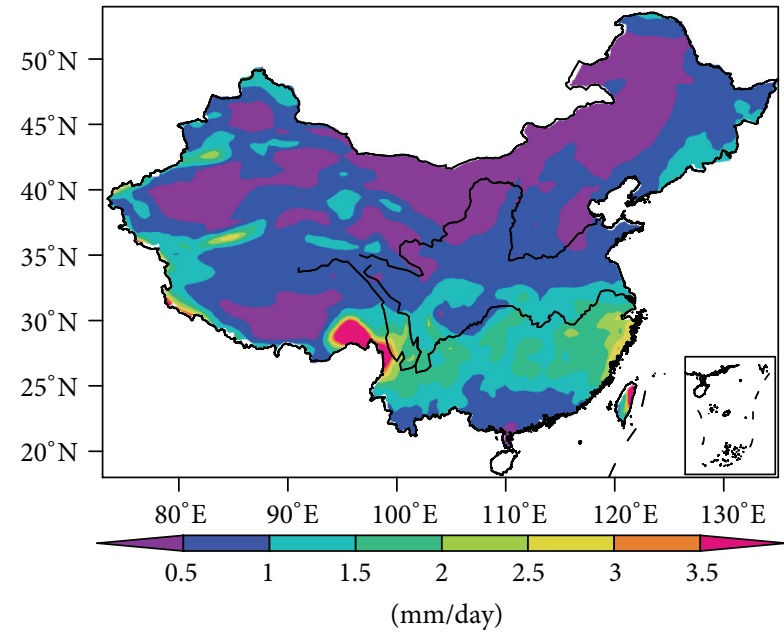

(a)

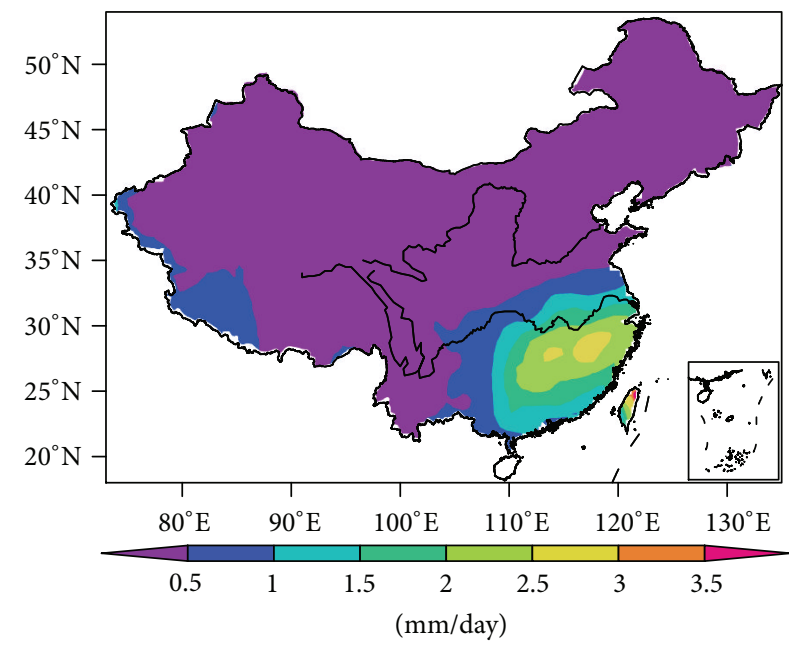

(c)

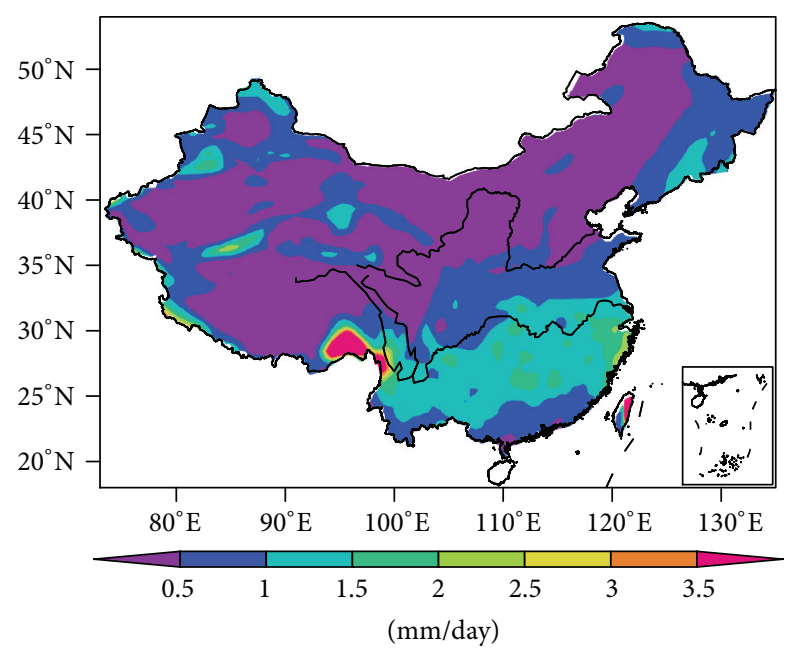

(b)

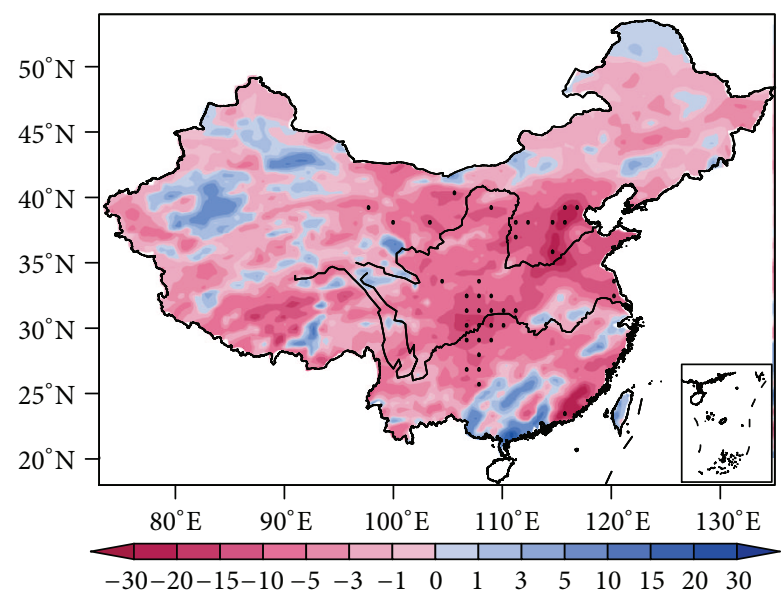

(\%)

(d)

FIGURE 10: Precipitation rate for (a) Nodust, (b) Dust, (c) CRU, and (d) percentage change between Dust and Nodust experiments averaged in winter during 2000-2009 period; the black dots in (d) indicate areas in which the difference is statistically significant at the $95 \%$ confidence level (Student's $t$-test).

Asian continent surface temperature decrease by about $1.5^{\circ} \mathrm{C}$ covering the Taklamakan Desert and Central-South China. The simulated dust radiative effect was stronger than the GCM work of Miller and Tegen [39].

Most previous researches mainly focused on the aerosol effect on the EASM, while the research about the aerosol effect on the EAWM was rare. Meanwhile, available studies show that there is a great uncertainty about the aerosol indirect effect on summer climate in East Asia [24, 63]. Therefore, present study involves only the dust direct effect on the EAWM. The cooling effect of dust aerosol enhanced the land-sea SLP gradient, thereby strengthening the EAWM. The enhanced East Asian winter cold and dry air suppressed the large-scale precipitation causing rainfall decreases in most areas of East Asia, especially Northeast China and the middle Yangtze River Valley, where the decline was about 10$30 \%$.
Modeling results could be sensitive to aerosol optical properties assumed in the model. For example, the perturbation of direct aerosol RF showed a great sensitivity to SSA in cloudy columns [64]. Recently, Colarco et al. [65] using NASA GEOS-5 atmospheric GCM explored the sensitivity of dust optical properties (e.g., dust shade and refractive) on dust emission and climate forcing over Saharan desert. They found that assumptions of the dust SSA in the model and the simulated dust radiative effects were closely related. Meanwhile, the value of SSA in Asia desert is still uncertain. Lee et al. [66] reported that the nationwide mean of SSA at $0.5 \mu \mathrm{m}$ is $0.89 \pm 0.04 \mu \mathrm{m}$ in China, and the work of Ge et al. [67] showed Asian dust SSA ranges from 0.74 to 0.84 at $0.5 \mu \mathrm{m}$. However, Costa et al. [68] found that it can be as low as 0.76 , which is much smaller than the value found for African dust. The smaller values of SSA for Asian dust suggest that these particles are strongly absorbing aerosols [64]. Since 


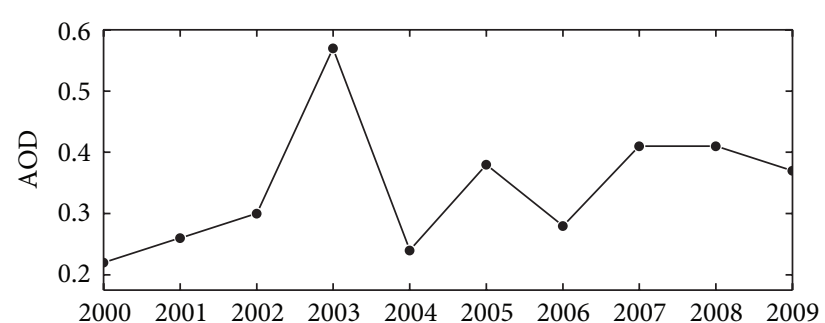

(a)

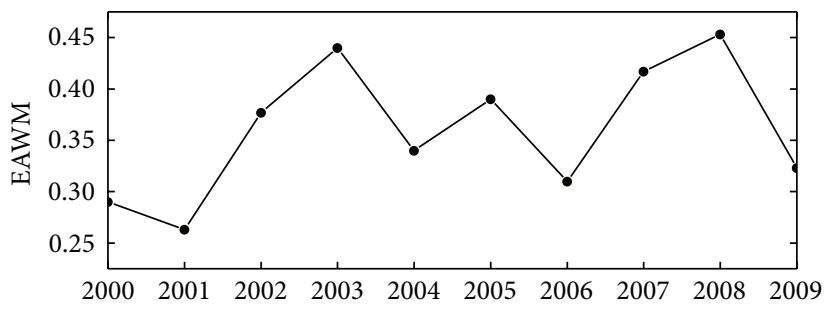

(c)

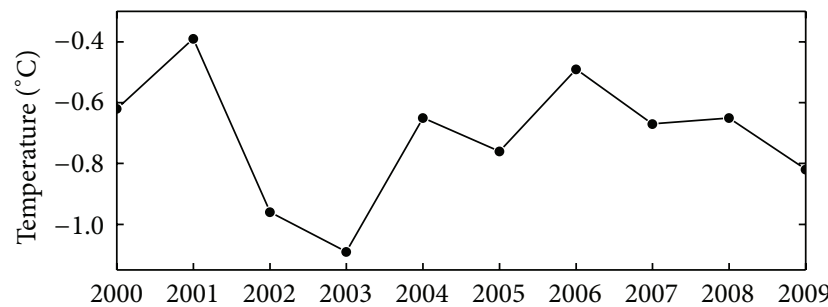

(b)

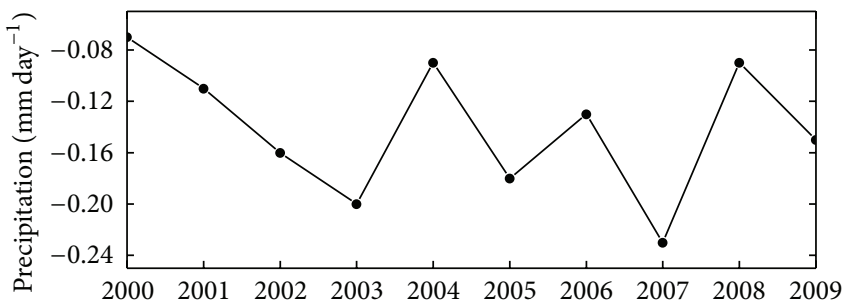

(d)

FIGURE 11: Year-to-year variations of winter dust AOD in the Taklamakan Desert in the Dust experiment (a), the difference in winter surface temperature in the Taklamakan Desert (b), the difference of EAWM index (c), and the difference in winter precipitation (d) in North China between Dust and Nodust experiments.

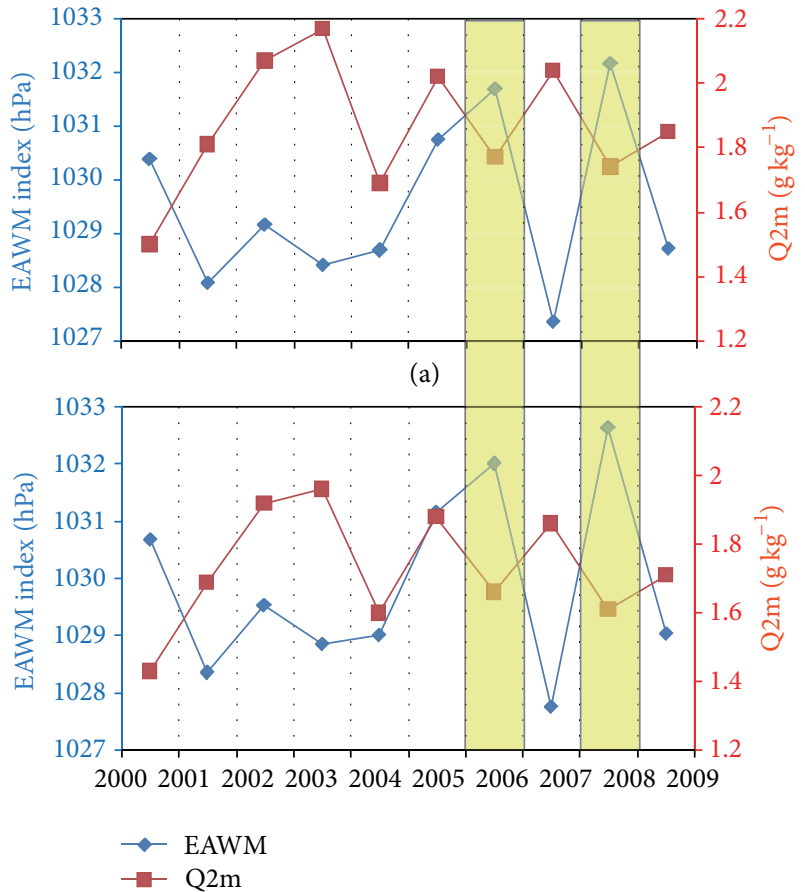

(b)

Figure 12: Year-to-year variations of the EAWM index and average winter water vapor mix ratio at $2 \mathrm{~m}$ above surface (Q2m) averaged in the Taklamakan Desert in Nodust experiment (a) and Dust experiment (b). The yellow columns represent strong monsoon years.

the high uncertainty of Asian dust SSA, our results in this paper also need to be validated by sensitivity experiments. In the future, we will carry out sensitivity experiments to explore the impacts of different assumptions of dust optical properties on the climate forcing over Asia.

Most previous studies were focused on the EASM. A recent modeling work using RegCM4/Dust studied dust effects on the EASM and found that dust can weaken the EASM [28]. Simulation work to date using high resolution regional climate model concerning the EAWM is rare. On the one hand, this study helps to fill the gaps in previous researches. On the other hand, it has a certain referential significance for quantification of dust contribution to the variability of the EAWM and also to understanding aeolian dust effects on the evolution of the EAWM. We only discussed the dust effects on the EAWM in this paper. Actually, the strength of Asian monsoon can in turn influence the distribution of regional aerosols. For example, the variation of midsummer aerosols over Eastern Asia is closely associated with the Asian summer monsoon activity [69]. When we tried to figure out the impact of intensity of winter monsoon on Asian dust emission by comparing the results between strong and weak winter monsoon years from the current simulation, we failed to detect a robust result. However, we found that the surface water vapor mixing ratio in the Dust experiment is lower than that in the Nodust experiment in strong winter monsoon years, which indicates that enhancement of winter monsoon may cause dust emissions increasing. Besides, observational study also found that the fluctuation of westerly jet has important links to the intensity of precipitation in the Taklamakan Desert [70]. In our future work, we will use this model to study the fluctuation of westerly jet on the East Asia dust cycle.

\section{Conflict of Interests}

The authors declare no conflict of interests. 


\section{Acknowledgments}

The authors thank the anonymous reviewers for their constructive comments and suggestions to improve the paper. They thank Dr. Buwen Dong for the language editing. This work was jointly supported by the Strategic Priority Research Program of the Chinese Academy of Sciences (XDA05110101), the National Basic Research Program of China (2011CB403406) and the National Science Foundation of China (41290255, 41405093), and the West Light Foundation of the Chinese Academy of Sciences.

\section{References}

[1] L. Zhang, H. Liao, and J. P. Li, "Impacts of Asian summer monsoon on seasonal and interannual variations of aerosols over eastern China," Journal of Geophysical Research D: Atmospheres, vol. 115, no. 7, Article ID D00K05, 2010.

[2] W. C. Hinds, Aerosol Technology, John Wiley \& Sons, New York, NY, USA, 2nd edition, 1999.

[3] D. G. Streets and S. T. Waldhoff, "Present and future emissions of air pollutants in China: $\mathrm{SO}_{2}, \mathrm{NO}_{x}$, and CO," Atmospheric Environment, vol. 34, no. 3, pp. 363-374, 2000.

[4] V. Ramanathan, P. J. Crutzen, J. T. Kiehl, and D. Rosenfeld, "Atmosphere: aerosols, climate, and the hydrological cycle," Science, vol. 294, no. 5549, pp. 2119-2124, 2001.

[5] Y. Huang, R. E. Dickinson, and W. L. Chameides, "Impact of aerosol indirect effect on surface temperature over East Asia," Proceedings of the National Academy of Sciences of the United States of America, vol. 103, no. 12, pp. 4371-4376, 2006.

[6] X. Y. Zhang, S. L. Gong, T. L. Zhao, R. Arimoto, Y. Q. Wang, and Z. J. Zhou, "Sources of Asian dust and role of climate change versus desertification in Asian dust emission," Geophysical Research Letters, vol. 30, no. 24, p. 2272, 2003.

[7] I. Uno, K. Harada, S. Satake, Y. Hara, and Z. Wang, "Meteorological characteristics and dust distribution of the Tarim Basin simulated by the nesting RAMS/CFORS dust model," Journal of the Meteorological Society of Japan, vol. 83, no. 3, pp. 219-239, 2005.

[8] W. H. Qian, L. S. Quan, and S. Y. Shi, "Variations of the dust storm in China and its climatic control," Journal of Climate, vol. 15, no. 10, pp. 1216-1229, 2002.

[9] Z. Q. Li, C. Li, H. Chen et al., "East Asian studies of tropospheric aerosols and their impact on regional climate (EAST-AIRC): an overview," Journal of Geophysical Research D: Atmospheres, vol. 116, no. 7, Article ID D00K34, 2011.

[10] Z. Q. Li, H. Chen, M. Cribb et al., "Preface to special section on East Asian studies of tropospheric aerosols: an international regional experiment (EAST-AIRE)," Journal of Geophysical Research, vol. 112, no. 22, Article ID D22S00, 2007.

[11] T. Logan, B. Xi, X. Dong, R. Obrecht, Z. Li, and M. Cribb, "A study of Asian dust plumes using satellite, surface, and aircraft measurements during the INTEX-B field experiment," Journal of Geophysical Research D: Atmospheres, vol. 115, no. 7, Article ID D00K25, 2010.

[12] J. Huang, P. Minnis, B. Chen et al., "Long-range transport and vertical structure of Asian dust from CALIPSO and surface measurements during PACDEX," Journal of Geophysical Research D: Atmospheres, vol. 113, no. 23, Article ID D23212, 2008.
[13] G. A. D’Almeida, "A model for Saharan dust transport," Journal of Climate \& Applied Meteorology, vol. 25, no. 7, pp. 903-916, 1986.

[14] I. Tegen and I. Fung, "Modeling of mineral dust in the atmosphere: sources, transport, and optical thickness," Journal of Geophysical Research, vol. 99, no. 11, pp. 22-914, 1994.

[15] E. Nowottnick, P. Colarco, R. Ferrare et al., "Online simulations of mineral dust aerosol distributions: comparisons to NAMMA observations and sensitivity to dust emission parameterization," Journal of Geophysical Research D: Atmospheres, vol. 115, no. 3, Article ID D03202, 2010.

[16] Y. Shao, Y. Yang, J. Wang et al., "Northeast Asian dust storms: real-time numerical prediction and validation," Journal of Geophysical Research D: Atmospheres, vol. 108, no. 22, pp. -1-18, 2003.

[17] S. L. Gong and X. Y. Zhang, "CUACE/Dust-an integrated system of observation and modeling systems for operational dust forecasting in Asia," Atmospheric Chemistry and Physics, vol. 8, no. 9, pp. 2333-2340, 2008.

[18] J. Sun and L. Zhao, "Numerical simulation of two East Asian dust storms in spring 2006," Earth Surface Processes and Landforms, vol. 33, no. 12, pp. 1892-1911, 2008.

[19] I. Tegen and A. A. Lacis, "Modeling of particle size distribution and its influence on the radiative properties of mineral dust aerosol," Journal of Geophysical Research D: Atmospheres, vol. 101, no. 14, pp. 19237-19244, 1996.

[20] I. N. Sokolik and O. B. Toon, "Direct radiative forcing by anthropogenic airborne mineral aerosols," Nature, vol. 381, no. 6584, pp. 681-683, 1996.

[21] Z. Levin, E. Ganor, and V. Gladstein, "The effects of desert particles coated with sulfate on rain formation in the eastern Mediterranean," Journal of Applied Meteorology, vol. 35, no. 9, pp. 1511-1523, 1996.

[22] D. Rosenfeld, Y. Rudich, and R. Lahav, "Desert dust suppressing precipitation: a possible desertification feedback loop," Proceedings of the National Academy of Sciences of the United States of America, vol. 98, no. 11, pp. 5975-5980, 2001.

[23] K. M. Lau, M. K. Kim, and K. M. Kim, "Asian summer monsoon anomalies induced by aerosol direct forcing: the role of the Tibetan Plateau," Climate Dynamics, vol. 26, no. 7-8, pp. 855864, 2006.

[24] X. Liu, X. Xie, Z.-Y. Yin, C. Liu, and A. Gettelman, "A modeling study of the effects of aerosols on clouds and precipitation over East Asia," Theoretical and Applied Climatology, vol. 106, no. 3-4, pp. 343-354, 2011.

[25] I. Tegen, S. P. Harrison, K. Kohfeld, I. C. Prentice, M. Coe, and M. Heimann, "Impact of vegetation and preferential source areas on global dust aerosol: results from a model study," Journal of Geophysical Research D: Atmospheres, vol. 107, no. 21, article 4576, 2002.

[26] C. Luo, N. M. Mahowald, and J. del Corral, "Sensitivity study of meteorological parameters on mineral aerosol mobilization, transport, and distribution," Journal of Geophysical Research D: Atmospheres, vol. 108, no. 15, pp. 1-21, 2003.

[27] D. F. Zhang, A. S. Zakey, X. J. Gao, F. Giorgi, and F. Solmon, "Simulation of dust aerosol and its regional feedbacks over East Asia using a regional climate model," Atmospheric Chemistry and Physics, vol. 9, no. 4, pp. 1095-1110, 2009.

[28] H. Sun, Z. T. Pan, and X. D. Liu, "Numerical simulation of spatial-temporal distribution of dust aerosol and its direct radiative effects on East Asian climate," Journal of Geophysical 
Research D: Atmospheres, vol. 117, no. 13, Article ID D13206, 2012.

[29] C. P. Chang and K. M. Lau, "Short-term planetary-scale interactions over the tropics and midlatitudes during northern winter. Part I: contrasts between active and inactive periods," Monthly Weather Review, vol. 110, no. 8, pp. 933-946, 1982.

[30] S. Q. Pei and C. Y. Li, "A further study on the East Asian winter monsoon and its influences. Part I: features of variation and anomaly," Climatic and Environmental Research, vol. 12, no. 2, pp. 124-136, 2007 (Chinese).

[31] C. Zhang and H. Zhang, "Potential impacts of East Asian winter monsoon on climate variability and predictability in the Australian summer monsoon region," Theoretical and Applied Climatology, vol. 101, no. 1-2, pp. 161-177, 2010.

[32] S. Yang, K.-M. Lau, and K.-M. Kim, "Variations of the East Asian jet stream and Asian-Pacific-American winter climate anomalies," Journal of Climate, vol. 15, no. 1, pp. 306-325, 2002.

[33] X. Y. Zhang, H. Y. Lu, R. Arimoto, and S. L. Gong, "Atmospheric dust loadings and their relationship to rapid oscillations of the Asian winter monsoon climate: two 250-Kyr loess records," Earth and Planetary Science Letters, vol. 202, no. 3-4, pp. 637643, 2002.

[34] H. C. Jiang and Z. L. Ding, "Eolian grain-size signature of the Sikouzi lacustrine sediments (Chinese Loess Plateau): implications for Neogene evolution of the East Asian winter monsoon," Bulletin of the Geological Society of America, vol. 122, no. 5-6, pp. 843-854, 2010.

[35] Z. K. Xu, T. G. Li, X. K. Yu et al., "Sediment provenance and evolution of the East Asian winter monsoon since $700 \mathrm{ka}$ recorded by major elements in the West Philippine Sea," Chinese Science Bulletin, vol. 58, no. 9, pp. 1044-1052, 2013.

[36] Y. F. Wu, R. J. Zhang, Z. W. Han, and Z. W. Zeng, "Relationship between East Asian Monsoon and dust weather frequency over Beijing," Advances in Atmospheric Sciences, vol. 27, no. 6, pp. 1389-1398, 2010.

[37] J.-Y. Yu, Y.-W. Wang, and C.-W. Chang, "Asian dust storm activity and its association with atmospheric circulation from 1995 to 2006," Terrestrial, Atmospheric and Oceanic Sciences, vol. 21, no. 2, pp. 375-391, 2010.

[38] M. Y. Jiao, R. Y. Niu, L. N. Zhao, and H. Yan, "Comparative analysis on causing factors of dust events," Journal of Desert Research, vol. 24, no. 6, pp. 696-700, 2004 (Chinese).

[39] R. L. Miller and I. Tegen, "Climate response to soil dust aerosols," Journal of Climate, vol. 11, no. 12, pp. 3247-3267, 1998.

[40] Z. Ji, S. Kang, D. Zhang, C. Zhu, J. Wu, and Y. Xu, "Simulation of the anthropogenic aerosols over South Asia and their effects on Indian summer monsoon," Climate Dynamics, vol. 36, no. 9-10, pp. 1633-1647, 2011.

[41] S. Das, S. Dey, S. K. Dash, and G. Basil, "Examining mineral dust transport over the Indian subcontinent using the regional climate model, RegCM4.1," Atmospheric Research, vol. 134, pp. 64-76, 2013.

[42] V. Artale, S. Calmanti, A. Carillo et al., "An atmosphere-ocean regional climate model for the Mediterranean area: assessment of a present climate simulation," Climate Dynamics, vol. 35, no. 5, pp. 721-740, 2010.

[43] B. Marticorena and G. Bergametti, "Modeling the atmospheric dust cycle: 1 . Design of a soil-derived dust emission scheme," Journal of Geophysical Research, vol. 100, no. D8, pp. 1641516430, 1995.
[44] S. C. Alfaro and L. Gomes, "Modeling mineral aerosol production by wind erosion: emission intensities and aerosol size distributions in source areas," Journal of Geophysical Research D: Atmospheres, vol. 106, no. 16, pp. 18075-18084, 2001.

[45] A. S. Zakey, F. Solmon, and F. Giorgi, "Implementation and testing of a desert dust module in a regional climate model," Atmospheric Chemistry and Physics, vol. 6, no. 12, pp. 46874704, 2006.

[46] M. Hess, P. Koepke, and I. Schult, "Optical properties of aerosolsand clouds: the software package OPAC," Bulletin of the American Meteorological Society, vol. 79, no. 5, pp. 831-844, 1998.

[47] J. Kiehl, J. Hack, G. Bonan et al., "Description of the NCAR community climate model (CCM3)," Technical Report of National Center for Atmospheric Research, 1996.

[48] H. Wang, G. Shi, S. Li, W. Li, B. Wang, and Y. Huang, "The impacts of optical properties on radiative forcing due to dust aerosol," Advances in Atmospheric Sciences, vol. 23, no. 3, pp. 431-441, 2006.

[49] R. W. Reynolds, N. A. Rayner, T. M. Smith, D. C. Stokes, and W. Wang, "An improved in situ and satellite SST analysis for climate," Journal of Climate, vol. 15, no. 13, pp. 1609-1625, 2002.

[50] Chinese Academy of Sciences, Chinese Desertification Map, Resource and Environment Database, Chinese Academy of Sciences, Beijing, China, 1998.

[51] M. Kanamitsu, W. Ebisuzaki, J. Woollen et al., "NCEP-DOE AMIP-II reanalysis (R-2)," Bulletin of the American Meteorological Society, vol. 83, no. 11, pp. 1631-1559, 2002.

[52] T. R. Loveland, B. C. Reed, J. F. Brown et al., "Development of a global land cover characteristics database and IGBP DISCover from $1 \mathrm{~km}$ AVHRR data," International Journal of Remote Sensing, vol. 21, no. 6-7, pp. 1303-1330, 2000.

[53] T. D. Mitchell and P. D. Jones, "An improved method of constructing a database of monthly climate observations and associated high-resolution grids," International Journal of Climatology, vol. 25, no. 6, pp. 693-712, 2005.

[54] Y. Zhang, K. R. Sperber, J. S. Boyle et al., "East Asian winter monsoon: results from eight AMIP models," Climate Dynamics, vol. 13, no. 11, pp. 797-820, 1997.

[55] W. Chen, H.-F. Graf, and R. Huang, "The interannual variability of East Asian Winter Monsoon and its relation to the summer monsoon," Advances in Atmospheric Sciences, vol. 17, no. 1, pp. 48-60, 2000.

[56] S. Yang and R. Lu, "Predictability of the East Asian winter monsoon indices by the coupled models of ENSEMBLES," Advances in Atmospheric Sciences, vol. 31, no. 6, pp. 1279-1292, 2014.

[57] Z. Shi and X. Liu, "Distinguishing the provenance of finegrained eolian dust over the Chinese Loess Plateau from a modelling perspective," Tellus, Series B: Chemical and Physical Meteorology, vol. 63, no. 5, pp. 959-970, 2011.

[58] X. T. Su, H. J. Wang, H. R. Tao, L. S. Liu, and H. F. Zhang, "Simulation on the spatio-temporal distribution and emission flux of dust aerosol over East Asia in 2000-2009," Sciences in Cold and Arid Regions, vol. 5, no. 2, pp. 230-239, 2013.

[59] D. Yihui, "Build-up, air mass transformation and propagation of Siberian high and its relations to cold surge in East Asia," Meteorology and Atmospheric Physics, vol. 44, no. 1-4, pp. 281292, 1990.

[60] C. T. Wang and L. Yu, "Sensitivity of regional climate model to different cumulus parameterization schemes in simulation 
of the Tibetan Plateau climate," Chinese Journal of Atmospheric Sciences, vol. 35, no. 6, pp. 1132-1144, 2011 (Chinese).

[61] D.-F. Zhang, X.-J. Gao, L.-C. Ouyang, and W.-J. Dong, "Simulation of present climate over East Asia by a regional climate model," Journal of Tropical Meteorology, vol. 14, no. 1, pp. 19-23, 2008.

[62] D.-Y. Gong, S.-W. Wang, and J.-H. Zhu, "East Asian winter monsoon and Arctic Oscillation," Geophysical Research Letters, vol. 28, no. 10, pp. 2073-2076, 2001.

[63] J. Huang, T. Wang, W. Wang, Z. Li, and H. Yan, "Climate effects of dust aerosols over East Asian arid and semiarid regions," Journal of Geophysical Research: Atmospheres, vol. 119, no. 19, pp. 11398-11416, 2014.

[64] N. G. Loeb and W. Su, "Direct aerosol radiative forcing uncertainty based on a radiative perturbation analysis," Journal of Climate, vol. 23, no. 19, pp. 5288-5293, 2010.

[65] P. R. Colarco, E. P. Nowottnick, C. A. Randles et al., "Impact of radiatively interactive dust aerosols in the NASA GEOS-5 climate model: sensitivity to dust particle shape and refractive index," Journal of Geophysical Research D: Atmospheres, vol. 119, no. 2, pp. 753-786, 2014.

[66] K. H. Lee, Z. Li, M. S. Wong et al., "Aerosol single scattering albedo estimated across China from a combination of ground and satellite measurements," Journal of Geophysical Research D: Atmospheres, vol. 112, no. 22, Article ID D22S15, 2007.

[67] J. M. Ge, J. Su, T. P. Ackerman, Q. Fu, J. P. Huang, and J. S. Shi, "Dust aerosol optical properties retrieval and radiative forcing over northwestern China during the 2008 China-U.S. joint field experiment," Journal of Geophysical Research D: Atmospheres, vol. 115, no. 13, Article ID D00K12, 2010.

[68] M. J. Costa, B.-J. Sohn, V. Levizzani, and A. M. Silva, "Radiative forcing of Asian dust determined from the synergized GOME and GMS satellite data-a case study," Journal of the Meteorological Society of Japan, vol. 84, no. 1, pp. 85-95, 2006.

[69] X. D. Liu, L. B. Yan, P. Yang, Z. Y. Yin, and G. R. North, "Influence of Indian summer monsoon on aerosol loading in East Asia," Journal of Applied Meteorology and Climatology, vol. 50, no. 3, pp. 523-533, 2011.

[70] R. Schiemann, D. Lüthi, and C. Schär, "Seasonality and interannual variability of the westerley jet in the Tibetan Plateau region," Journal of Climate, vol. 22, no. 11, pp. 2940-2957, 2009. 

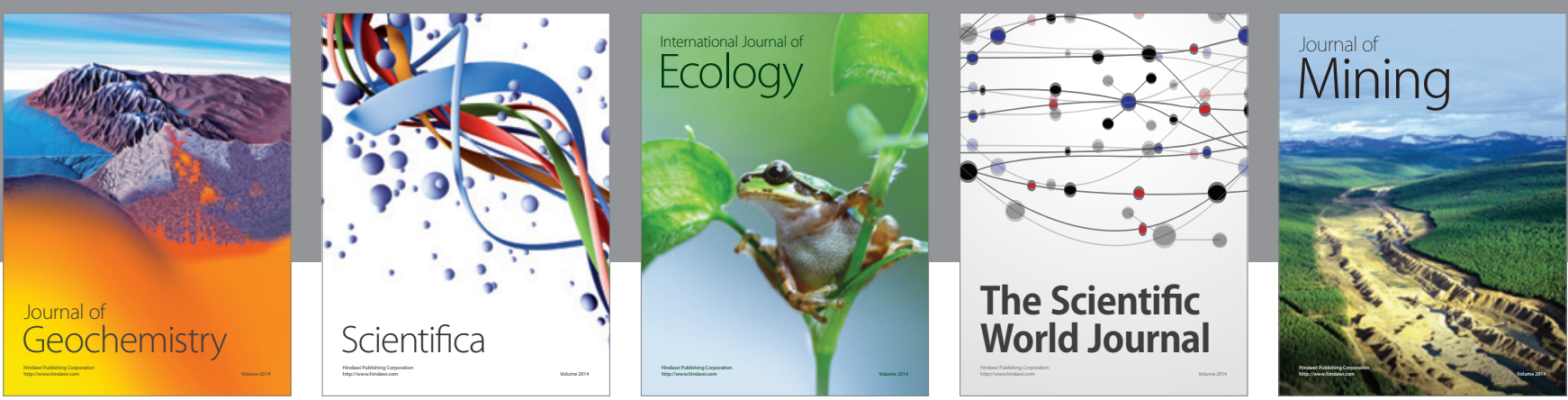

The Scientific World Journal
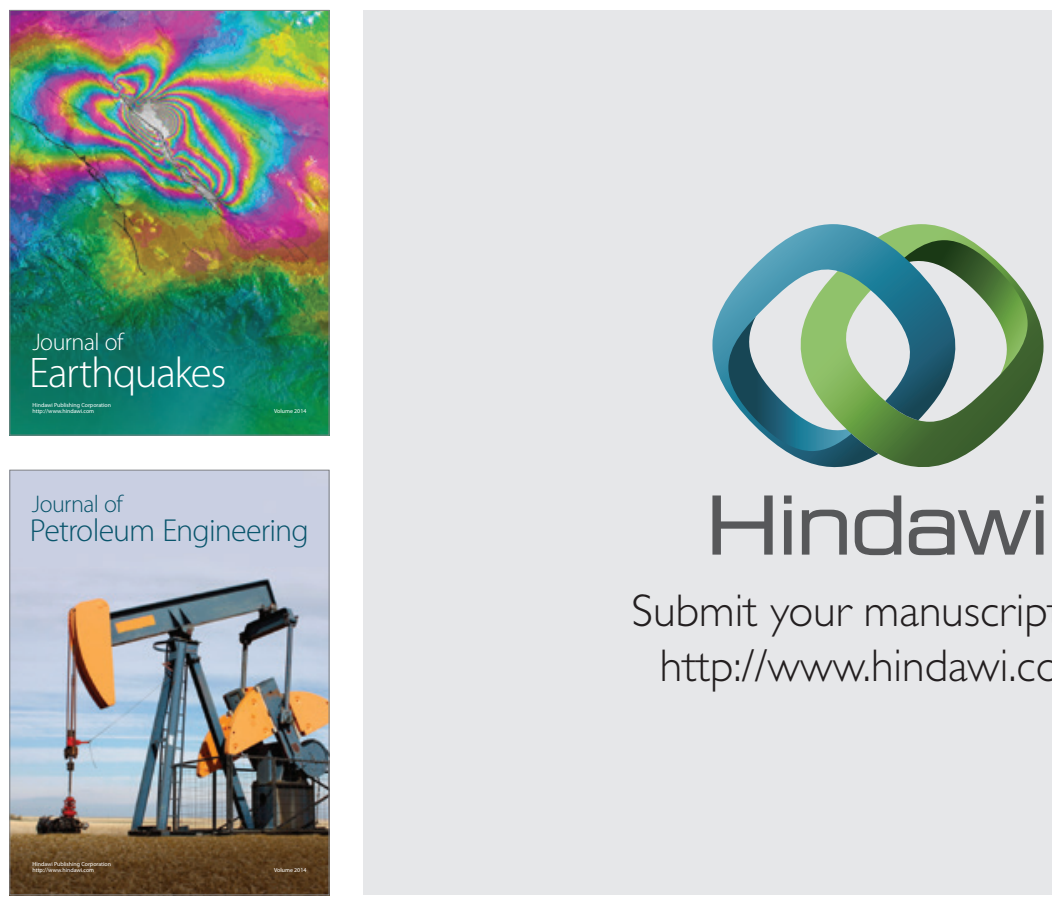

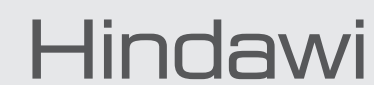

Submit your manuscripts at

http://www.hindawi.com
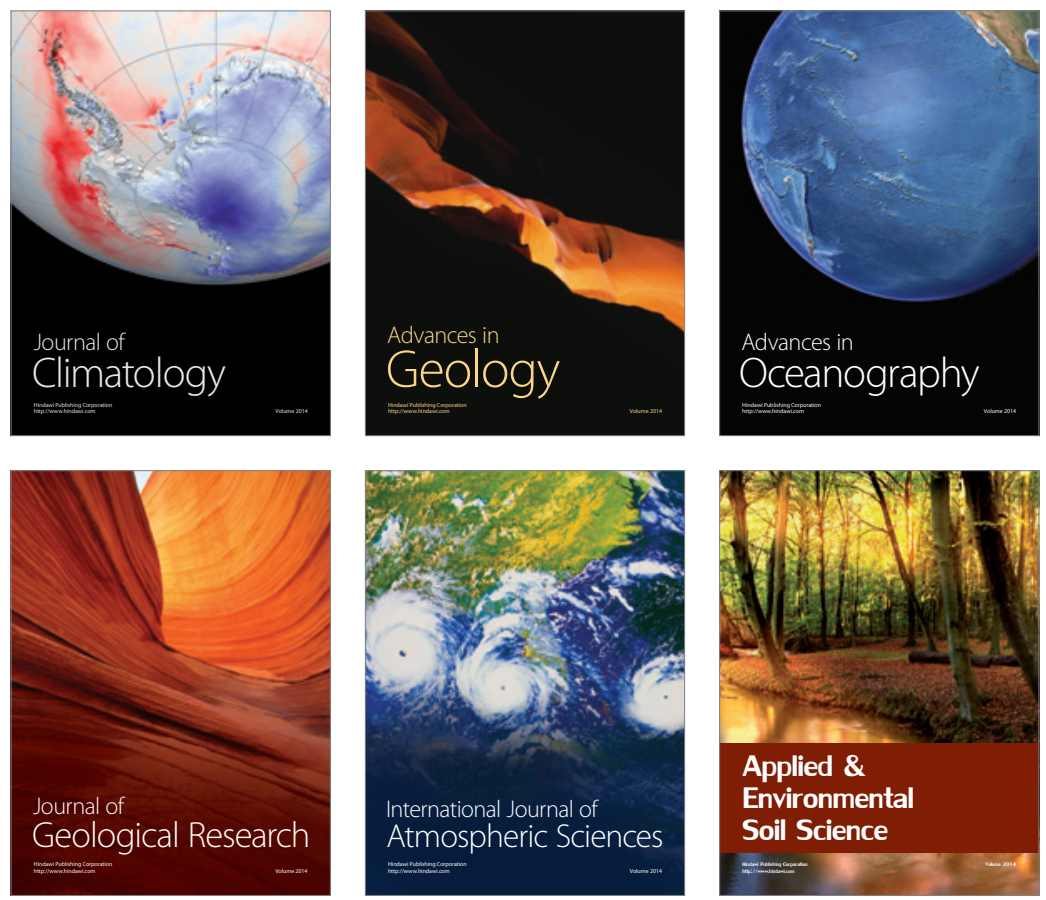
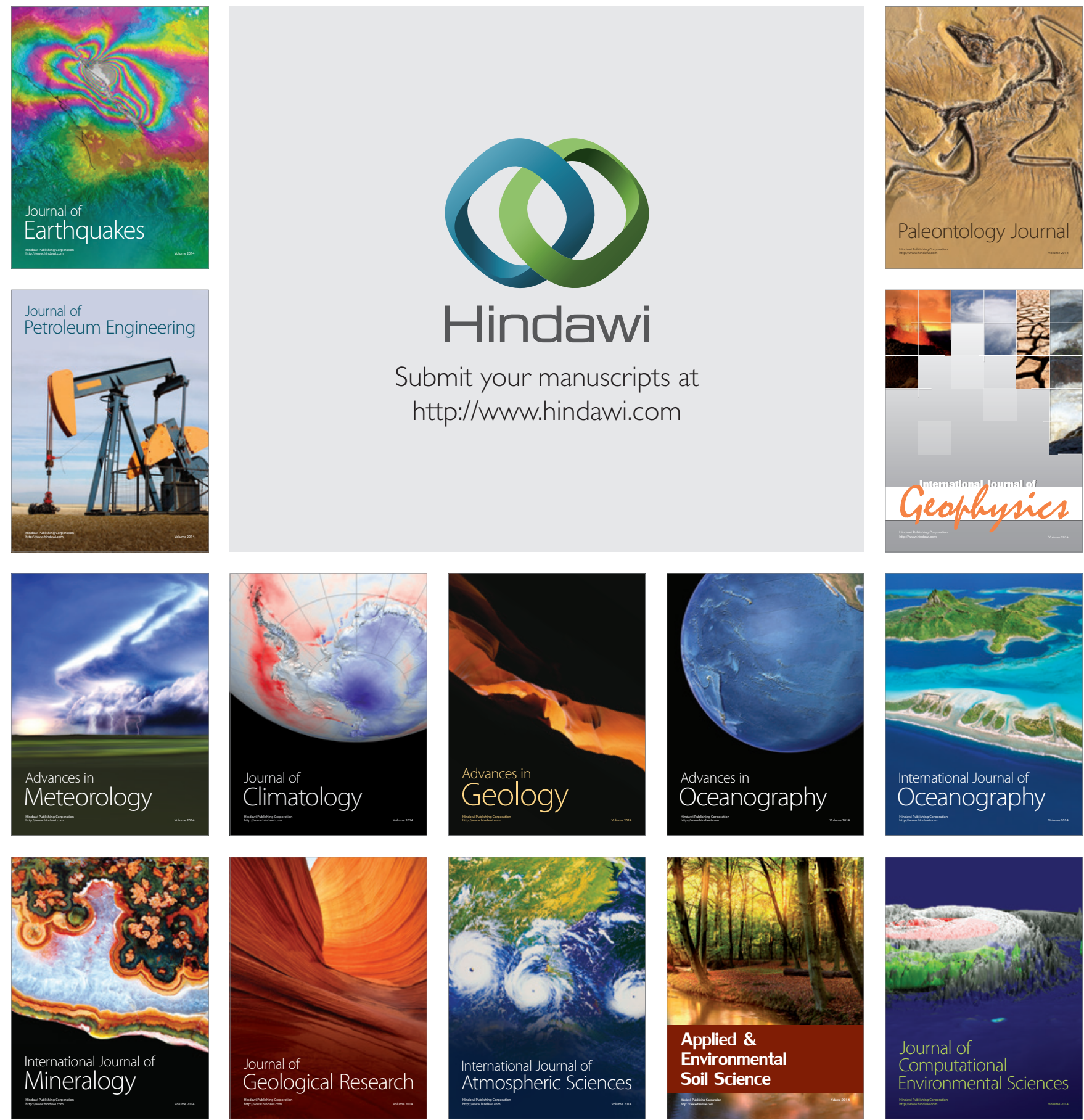